\title{
Taxonomic implications of geographical variation in Rhinolophus affinis (Chiroptera: Rhinolophidae) in mainland Southeast Asia
}

Saveng Ith ${ }^{1,2,3^{*}}$, Sara Bumrungsri ${ }^{2}$, Neil M Furey ${ }^{3,4}$, Paul JJ Bates ${ }^{5}$, Monwadee Wonglapsuwan ${ }^{6}$, Faisal Ali Anwarali Khan ${ }^{7}$, Vu Dinh Thong ${ }^{8}$, Pipat Soisook ${ }^{9}$, Chutamas Satasook ${ }^{2}$ and Nikky M Thomas ${ }^{5}$

\begin{abstract}
Background: Rhinolophus affinis sensu lato is distributed throughout Southeast Asia. The taxonomic status of forms attributed to the species is unclear due to the limited sample size with incomplete datasets and the taxa have high variation in morphology and echolocation call frequency. The aim of the study was to evaluate the distribution and taxonomic status of the subspecific forms of $R$. affinis in mainland Southeast Asia using large sample size with multiple datasets, including morphological, acoustic, and genetic data, both to elucidate taxonomic relationships and to test for congruence between these datasets.
\end{abstract}

Results: Three morphological forms were confirmed within the region; two concur with previously recognized taxa, namely $R$. affinis macrurus and $R$. affinis superans, and are strongly supported by morphological and genetic data. The third form is morphologically distinct, but its taxonomic status remains unclear. It is probable that this third form represents a distinct taxonomic entity; however, more data are required to confirm this. R. a. macrurus is known from the north of peninsular Thailand, Cambodia, Myanmar, Laos, and Vietnam (Indochinese subregion); R. a. superans is found throughout the Thai-Malay Peninsula (Sundaic subregion); whilst the third form is presently known from east central Myanmar (Shan state) and lower northern Vietnam (Nghe An Province).

Conclusions: Our results suggest that at least three morphological forms occur in mainland Southeast Asia including one form which appears to be new to science. Echolocation call data for $R$. affinis are not a robust taxonomic tool as it shows a significant degree of variation which is not explained or supported by genetic and morphological findings. This study highlights significant levels of morphological variation in mainland Southeast Asia and provides an essential basis for further studies aiming to understand the population genetics, phylogeography, and taxonomy of the species.

Keywords: Rhinolophus affinis; Subspecies; Morphology; Echolocation; Genetics; Indochinese subregion; Sundaic subregion

\section{Background}

Rhinolophus Lacépède is the only genus in the Old World family Rhinolophidae Gray (Corbet and Hill 1992). All members of this family are characterized by the presence of a horseshoe-shaped anterior nose leaf, the morphology of which can be diagnostic between species. Other characters

\footnotetext{
* Correspondence: pheaveng@gmail.com

'Department of Biology, Faculty of Science, Royal University of Phnom Penh, Confederation of Russia Boulevard, Phnom Penh 12150, Cambodia

${ }^{2}$ Department of Biology, Faculty of Science, Prince of Songkla University, 15

Karnjanavanich Street, Hat Yai, Songkhla 90110, Thailand

Full list of author information is available at the end of the article
}

commonly used to distinguish rhinolophid species include external and craniodental measurements, the presence or absence and position of the anterior upper premolar, and the number of mental grooves in the lower lip (Csorba et al. 2003; Hill 1959; Hill and Schlitter 1982). Constant frequency of the echolocation call emitted by these bats also has been proposed as a means for species-level distinction for this genus (Csorba et al. 2003; Kingston and Rossister, 2004; Ith et al. 2011; Soisook et al. 2008; Thong 2011). However, in many cases, data for these characters overlap, making genetic analysis an important additional

\section{实}

(C) 2015 Ith et al.; licensee Springer. This is an Open Access article distributed under the terms of the Creative Commons Attribution License (http//creativecommons.org/licenses/by/40), which permits unrestricted use distribution, and reproduction in any medium, provided the original work is properly credited. 
tool for resolving species identifications (Cooper et al. 1998; Li et al. 2006; Maharadatunkamsi et al. 2000; Patrick et al. 2013).

The intermediate horseshoe bat, Rhinolophus affinis Andersen, is a medium-sized bat (forearm length 45 to $56 \mathrm{~mm}$ ) distributed widely in South and Southeast Asia, including northern India (including Andaman Islands), Nepal to southern China, mainland Southeast Asia, Borneo, Java, and nearby islands (Francis 2008; Simmons 2005). The taxon includes nine recognized subspecies throughout its range: $R$. affinis affinis Horsfield (type locality Java), $R$. a. andamanensis Dobson (type locality South Andaman Island), $R$. a. himalayanus Andersen (type locality Mussoorie, Kumaon Division, northern India), $R$. a. tener Andersen (type locality Pegu Division, recently known as Bago, Myanmar), R. a. macrurus Andersen (type locality Taho, Karennee, Kyah State, Myanmar), $R$. a. superans Andersen (Pahang, peninsular Malaysia), $R$. a. nesite Andersen (type locality Bunguran Island, North Natunas, Indonesia), $R$. a. princeps Andersen (type locality Lombok, Lesser Sunda Island), and $R$. a. hainanus Allen (type locality Pouten, Hainan Island). The geographical scope of the present study is limited to mainland Southeast Asia and as such includes the range of three of these forms (Andersen 1905): $R$. a. tener, $R$. a. macrurus, and $R$. a. superans. $R$. a. tener is a small rhinolophid with a short tail and a relatively large horseshoe; $R$. $a$. macrurus is described as being more moderate in size with large ears, a long tail, and a broad horseshoe (Sinha 1973); while $R$. a. superans is described as similar to R. macrurus but with short tail (Andersen 1905).

Lekagul and McNeely (1977) recognized two subspecific forms from Thailand: $R$. a. macrurus and $R$. a. superans. $R$. a. macrurus was recorded from Chiang Mai, Mae Sariang, and Mae Hong Son in the north of the country, while $R$. a. superans was recorded from peninsular Thailand (Andersen 1905; Lekagul and McNeely 1977). Consistent with this, Kingsada et al. (2011) referred specimens from the north of peninsular Thailand, Cambodia, and Vietnam to $R$. a. macrurus, and the form from peninsular Thailand to $R$. a. superans on the basis of the peninsular form being larger on average and having a lower echolocation call frequency, 66.7 to 71.3 $\mathrm{kHz}$ vs. 70.0 to $76.1 \mathrm{kHz}$ in $R$. a. superans. The findings of Kingsada et al. (2011) broadly agree with the morphological transition rule proposed by Andersen (1905) for $R$. affinis subspecies, namely: 'the more southern or southeastern the habitat, the longer the ears, the broader the horseshoe, the longer the tibia, the larger the skull, the broader the nasal swellings, and the longer the toothrows.' The third form known from the region, $R$. a. tener, is very poorly known, with no further information being available regarding status and distribution since the original description by Andersen (1905).
The current study is motivated by the extensive variation recorded in the frequency of maximum energy of echolocation call across the species' geographic range, with a difference of almost $20 \mathrm{kHz}$ between extremes: $66.7 \mathrm{kHz}$ being recorded from peninsular Thailand (Kingsada et al. 2011) and $84.5 \mathrm{kHz}$ from central Vietnam (Thong 2011). Acoustic analysis has revealed the existence of cryptic taxa among other Asian bat species that are morphologically similar but acoustically divergent (Kingston et al. 2001; Kingston and Rossister 2004; Soisook et al. 2008; Thabah et al. 2006), and such variation has yet to be fully explored in $R$. affinis. As such, this paper reviews the distribution and taxonomic status of forms of the species in mainland Southeast Asia using multiple datasets, including morphological, acoustic, and genetic data, both to elucidate taxonomic relationships and to test for congruence between these datasets.

\section{Methods}

\section{Sample collection and study sites}

A total of 170 specimens were examined from mainland Southeast Asia. Samples examined were from existing museum collections and those arising from recent surveys. Specimens were examined from collections held at Princess Maha Chakri Sirindhorn Natural History Museum, Prince of Songkla University, Thailand [PSU collection]; Zoological Collection, Centre for Biodiversity Conservation, Cambodia (CBC); Harrison Institute, UK (HZM); Institute of Ecology and Biological Resources (IEBR), Vietnam; Natural Science and Research Laboratory at Museum of Texas Tech University; and Zoological Museum at University Malaysia Sarawak and Kim Hy Nature Reserve Collection (NF), Vietnam.

Specimens were collected by Saveng Ith and team (Small Mammals and Birds Research Unit Team, PSU, Thailand) between November 2010 and March 2012 from survey sites in Thailand. Animals were captured in the field using a combination of harp traps, mist net, and hand nets.

Many specimens from Cambodia, Thailand, and Vietnam were previously included in Kingsada et al. (2011). All specimens and surveyed localities and habitats for the current study are listed below and in Appendix 1 (Figure 1).

\section{Cambodia}

Siem Reap Province: [C1] Phnom Kbal Spean, Banteay Srei District, and Phnom Kulen National Park (14 21' $\mathrm{N} 107^{\circ} 22^{\prime} \mathrm{E}$ ). Six males (five adult males and one sub adult) and one nulliparous female were collected by Ben Hayes, Sarith Pen, and Sophany Pauk between January and July 2010 on the mountain of evergreen forest. [C2] Ka Kek, Preah Vihear Protected Forest (14. 04' N $105^{\circ}$ $\left.17^{\prime} \mathrm{E}\right)$. One nulliparous female was captured by Gabor 


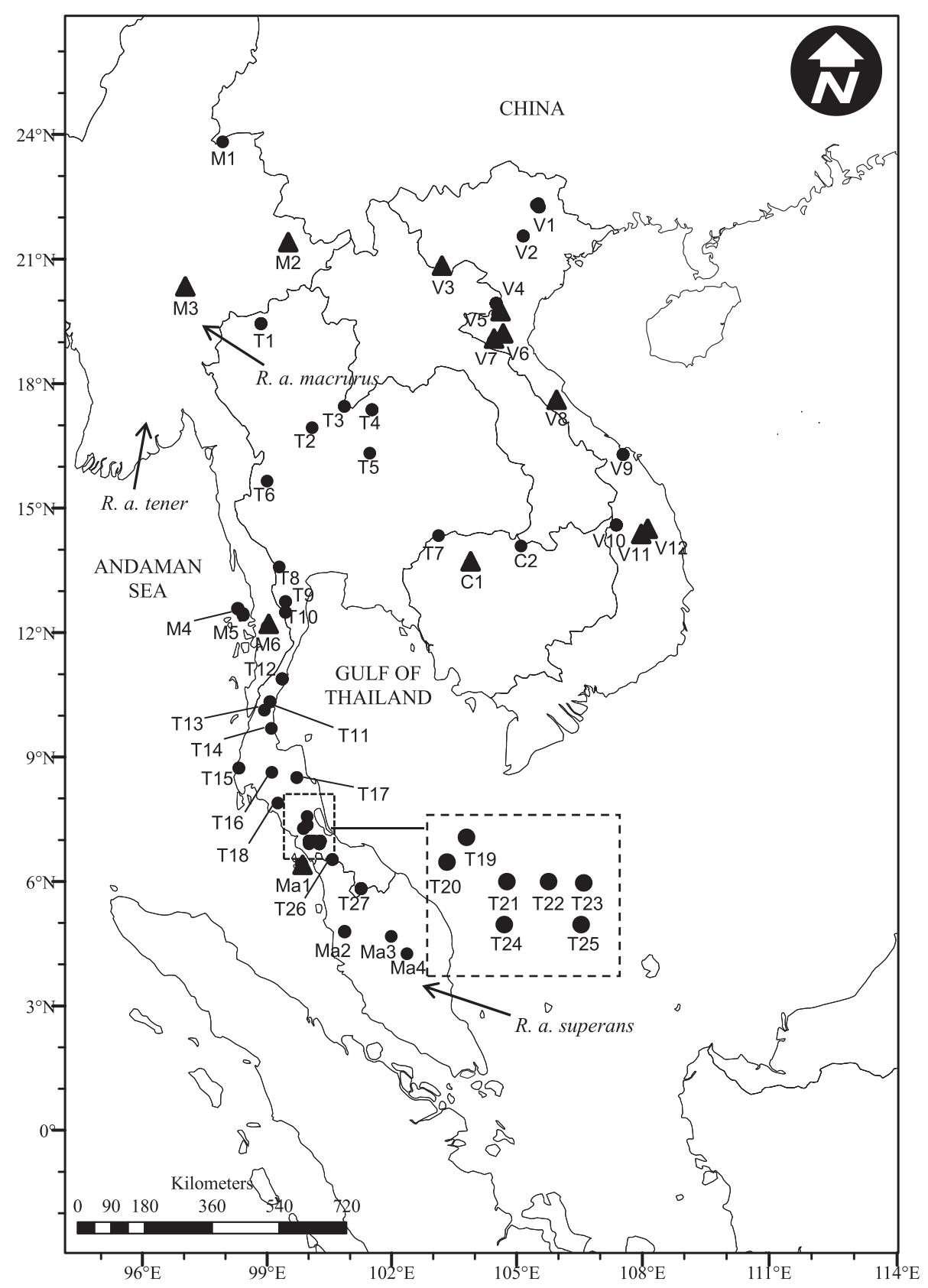

Figure 1 Collection localities of Rhinolophus affinis from mainland Southeast Asia. $C=$ Cambodia, $M=$ Myanmar, $M a=M a l a y s i a, T=$ Thailand, and V = Vietnam. Black circles are localities where materials were examined (based on sample collection and study sites in methodology and Appendix 1). The arrows indicate the type localities of the subspecies in the research area.

Csorba, Neil Furey, and Saveng Ith on 17 February 2011 in semi evergreen forest.

\section{Peninsular Malaysia}

Kedah State: [Ma1] Langkawi Island (approximately $6^{\circ}$ 23.204' N, 99 47.831' E). An adult male was collected by Mohd Isham Mohd Azhar; Penang State [Ma2] $\left(05^{\circ}\right.$ $\left.15^{\prime} 795 \mathrm{~N}, 100^{\circ} 29^{\prime} 076 \mathrm{E}\right)$. A nulliparous female was collected by Faisal Ali Anwarali Khan on 15 June 2011; Kelantan State: [Ma3] Gua Madu, Gua Musang Division (approximately $5^{\circ} 10.462^{\prime} \mathrm{N}, 101^{\circ} 54.191^{\prime} \mathrm{E}$ ). A parous female was captured by Faisal Ali Anwarali Khan on 24 June 2011; Pahang State: [Ma4] Nature Study of Kuala Atok, Taman Negara National Park (04' 16' 281 N, 102 22' 316 E). One adult male and one nulliparous female were collected by Faisal Ali Anwarali Khan on 19 to 22 May 2008. 


\section{Myanmar}

Shan State: [M1] Mant Hai Village, Muse Twonship $\left(23^{\circ}\right.$ 54' 962 N, 97 49' 000 E); [M2] Holin Village, Keng Taung (21 27' 483 N, 99 32' 000 E); [M3] Taung Pauk Village, Inle Lake (20 $\left.21^{\prime} 175 \mathrm{~N}, 96^{\circ} 53^{\prime} 189 \mathrm{E}\right)$. Three adult males and one female were collected by Paul Bates and Iain Mackie between March 2002 and December 2003. All areas were on the Shan plateau in areas of limestone karst, comprising limestone outcrops, deforested agricultural land and small patches of deciduous forest. Taninthary Division: [M4] Katalu Village, $\left(12^{\circ} 28^{\prime}\right.$ 436 N, 98 24' 191 E); [M5] Kyi Village (12³0' 113 N, $\left.98^{\circ} 24^{\prime} 333 \mathrm{E}\right)$, Kadan ID; specimens were collected in mist nets over a stream in open heavily degraded forest and agricultural land and from a roost in granite boulders in secondary forest; [M6] Hnedchey Khan Cave, Kyauk Taun Village (12 $11^{\prime} 400$ N, 99 $00^{\prime} 600$ E). The cave is in a limestone outcrop and surrounded by patches of degraded evergreen forest and agricultural land. One adult male and four females were collected by Paul Bates and Iain Mackie between June and November 2003.

\section{Thailand}

Chiang Mai Province: [T1] Khun Mae Ngai Ranger Station, Chiang Dao Wildlife Sanctuary (approximately $19^{\circ}$ $\left.30.556^{\prime} \mathrm{N}, 98^{\circ} 49.956^{\prime} \mathrm{E}\right)$. A sub-adult female was collected in a harp trap on 28 June 2011 in hilly evergreen forest (approximately 19 $31^{\prime} 55^{\prime \prime} \mathrm{N}, 98^{\circ} 50^{\prime} 26^{\prime \prime} \mathrm{E}$; 864 $\mathrm{m}$ a.s.l); two adult males, one parous female, and one nulliparous female were captured by Pipat Soisook between August 2005 and October 2006. Bats were captured from the limestone cave surrounded by orchards, mixed deciduous, and bamboo forest. Petchaboon Province: [T2] Nhong Mae Na, Thung Sa Lang Luang National Park (16.34' $\left.17^{\prime \prime} \mathrm{N}, 100.52^{\prime} 35^{\prime \prime} \mathrm{E}\right)$. One adult male was captured by Charles Francis and Sara Bumrungsri on 16 May 2006 in semi evergreen forest. Loei Province: [T3] Na Haeo District, Phu Suan Sai National Park (17 30' $19^{\prime \prime}$ $\mathrm{N}, 100^{\circ} 56^{\prime} 18^{\prime \prime} \mathrm{E}, 620 \mathrm{~m}, 975 \mathrm{~m}$ a.s.l). Two adult males were captured by Sara Bumrungsri and Charles Francis on 18 to 20 May 2006. Bats were captured using harp traps set across the trails within evergreen forest mixed with bamboo; [T4] Phu Ruea District, Phuluang Wildlife Sanctuary $\left(17^{\circ} 25^{\prime} 742 \mathrm{~N}, 101^{\circ} 38^{\prime} 006 \mathrm{E}\right)$. Three adult males and one nulliparous female were collected by Sara Bumrungsri and team on 17 to 18 March 1993. The habitat is unknown. Chaiyapum Province: [T5] Thung Kamang, Khon San District, Phukieo Wildlife Sanctuary $\left(16^{\circ} 18^{\prime} \mathrm{N}, 101^{\circ} 52^{\prime} \mathrm{E}\right)$. One nulliparous female was captured by Pipat Soisook on 08 April 2006 in hilly semi evergreen forest. Tak Province: [T6] Kavackee, East Thung Yai Naresuan Wildlife Sanctuary $\left(15^{\circ} 42^{\prime}\right.$ $\left.26^{\prime \prime} \mathrm{N}, 98^{\circ} 59^{\prime} 28^{\prime \prime} \mathrm{E}\right)$. One adult male was captured by Sara Bumrungsri on 11 March 2003 in semi evergreen forest. Surin Province: [T7] Ta Muen Thom, Huai Thap Than-Huay Sumran Wildlife Sanctuary (14 ${ }^{\circ}$ $\left.21^{\prime} 08^{\prime \prime} \mathrm{N}, 103^{\circ} 15^{\prime} 54^{\prime \prime} \mathrm{E}\right)$. One adult male was captured by Sara Bumrungsri on 28 January 2000 in dry semi evergreen forest. Ratchaburi Province: [T8] Mae Nam Pha Chi Wildlife Sanctuary $\left(1^{\circ} 18^{\prime} 142\right.$ N, 99 $25^{\prime} 009$ E). A male adult was captured by a harp trap set over a seasonal stream in dry evergreen forest by Pipat Soisook on 20 January 2008. Petchaburi Province: [T9] Kaeng Kra Chan National Park (approximately $12^{\circ} 47^{\prime} 965 \mathrm{~N}, 99^{\circ} 27^{\prime} 812 \mathrm{E}$ ). Two adult males and one nulliparous female were collected by Saveng Ith and team in August 2011. Three harp traps and two nets were set in bamboo forest, across a stream and a trail in evergreen forest. Prachuap Kiri Khan Province: [T10] Pa La-ou Ranger Station, Kaeng Kra Chan National Park (approx. 12³2' 228 N, 99 27' 812 E). Two adult males and one nulliparous female were collected by Saveng Ith in August 2011. Three harp traps were set on forest trails in evergreen forest. Ranong Province: [T11] Klong Sai On Waterfall, Krom Luang Chumpon Wildlife Sanctuary (10²2' 21 N, 99 04' 27 E). Three adult males and one nulliparous female were collected by Saveng Ith in August 2011. Three harp traps were set on forest trails of evergreen forest and surrounded rubber plantation and fruit orchards. Chumphon Province: [T12] Khao Kram cave, Patiew District $\left(10^{\circ} 55^{\prime} 08^{\prime \prime} \mathrm{N}, 99^{\circ} 22^{\prime} 26^{\prime \prime} \mathrm{E}, 67 \mathrm{~m}\right.$ a.s.l). Three adult males and three nulliparous females were captured by Sara Bumrungsri and team on 10 October 2006. The harp trap was set across the entrance of the cave surrounded by rubber plantation; [T13] Huay Wang Cave, Tumbon Khao Talu, Sawi District (10 $10^{\prime}$ $00^{\prime \prime} \mathrm{N}, 98^{\circ} 55^{\prime} 11^{\prime \prime} \mathrm{E}, 55 \mathrm{~m}$, a.s.l). One adult male was captured by Sara Bumrungsri and team on 10 January 2007. The harp trap was set across the entrance of a limestone cave surrounded by deciduous forest and rubber plantation; [14] Klao Plu Cave, Lamae District $\left(09^{\circ} 43^{\prime} 36^{\prime \prime} \mathrm{N}, 99^{\circ} 06^{\prime} 30^{\prime \prime} \mathrm{E}\right)$. One adult male was captured by Sara Bumrungsri and team on 09 January 2007. Harp traps were set across the trails in rubber plantation and fruit orchards. Pang Nga Province: [T15] North Surin Island (approximately 8 46' 200 N, $98^{\circ} 18^{\prime} 600$ E). Two adult males were collected by Sara Bumrungsri on 02 February 2006. The specimens were captured in a harp trap set over the trail on hill side surrounded by evergreen forest and close to the beach. Surat Thani Province: [T16] Rajjaprabha Dam (close to people settlements and farms) and Khlong Saeng Wildlife Sanctuary (approximately $7 \mathrm{~km}$ north of the reservoir) (approximately $8^{\circ} 58^{\prime} 885 \mathrm{~N}, 97^{\circ} 47^{\prime} 706 \mathrm{E}$ ). One adult male was collected by Saveng Ith on 31 August 2011 and one adult male was collected by Sara Bumrungsri on 17 
January 2012. The harp traps and mist nets were set on small trails and streams surrounded by disturbed evergreen forest, rubber plantations, and a mixed fruit orchard. Nakhon Si Thammarat Province: [T17] Khao Phlu Cave, Khao Ro Commune, Ron Piboon District ( $8^{\circ} 32^{\prime}$ 250 N, 99 43' 396 E). One adult male and nulliparous female were collected by Sara Bumrungsri from the cave on 15 October 2011. The cave is located in a limestone outcrop surrounded by rubber and oil palm plantations. Krabi Province: [T18] Khao Pra Bang Kram Wildlife Sanctuary ( $\left.7^{\circ} 55^{\prime} 31 \mathrm{~N}, 99^{\circ} 15^{\prime} 47 \mathrm{E}\right)$. One adult male was collected by Pipat Soisook on 04 May 2012. A harp trap was set across forest trail surrounded by lowland evergreen forest. Pattalung Province: [T19] Khao Ban Tad Wildlife Sanctuary (approximately $7^{\circ} 23^{\prime} 48 \mathrm{~N}, 99^{\circ} 58^{\prime} 40 \mathrm{E}$ ). Two adult males, one parous female and one nulliparous female were collected by Pipat Soisook in March 2012 using harp traps and mist nets set in evergreen forest across a stream and forest trail. Trang Province: [T20] Sai Rung Waterfall, Khao Ban Tad Wildlife Sanctuary (7 $18^{\prime} 080$ N, 99 41' 988 E). One adult male and two nulliparous females were collected by Pipat Soisook on 09 January 2011. Three harp traps and a mist net were set on forest trails and across a stream. Songkhla Province: [T21] Khuan Khao Wang Forest Park, Rattaphum District $\left(7^{\circ} 00^{\prime} 776\right.$ N, $100^{\circ} 01^{\prime} 259$ E). Four adult males and two nulliparous females were captured by Saveng Ith in August 2011 and February 2012. Mist nets and harps were set on the forest trails and across the small streams in evergreen forest surrounded by rubber plantation and fruit orchards; [T22-25] Ton Nga Chang Wildlife Sanctuary (approximately 6 ${ }^{\circ} 55^{\prime} 783$ N, 100 16' 299 E) including Boripatr Waterfall, Pha Dam Ranger Station, Makling Waterfall, and Hin Sam Kon Waterfall. Fifteen adult males and four nulliparous females were collected using harp traps and mist nets by Saveng Ith in February 2012 and Sara Bumrungsri between October 2006 and January 2007. The traps and nets were set on small trails and streams surrounded by evergreen forests and a rubber plantation; [T26] Khao Namkhang National Park (6 33' $\left.108 \mathrm{~N}, 100^{\circ} 16^{\prime} 299 \mathrm{E}\right)$. Two adult males were captured by hoop net in a man-made tunnel by Saveng Ith on 16 May 2012. Narathiwat Province: [T27] Hala Bala Wildlife Sanctuary $\left(05^{\circ} 47^{\prime} 54^{\prime \prime}\right.$ N, $101^{\circ} 49^{\prime} 30^{\prime \prime}$ E). Six adult males and two nulliparous females were collected by Saveng Ith in January 2012. Harp traps were set on forest trails in evergreen forest nearby the Wildlife Sanctuary Station.

\section{Vietnam}

Bac Kan Province: [V1] Kim Hy Nature Reserve (22 $2^{\circ} 1^{\prime}$ $\left.320^{\prime} \mathrm{N}, 106^{\circ} 03^{\prime} 530 \mathrm{E}\right)$. One immature male and seven parous females were captured by Neil Furey between June 2006 and February 2007. Bats were captured using mist net set in primary forest ridge. Vinh Phuc Province:
[V2] Tam Dao National Park (21 $30^{\circ} 448$ N, 105 36' 4,924 E). Five adult males were collected by $\mathrm{Vu}$ Dinh Thong on 24 November 2009. Son La Province: [V3] Tin To Area, Sop Cop Nature Reserve $\left(20^{\circ} 49^{\prime} 758\right.$ N, $\left.103^{\circ} 29^{\prime} 519 \mathrm{E}\right)$. Three adult males were collected in November 2004 by Pham Duc Tien. Nghe An Province: four sites were surveyed including [V4] Que Phong District, $\mathrm{Pu}$ Hoat Nature Reserve (approximately $19^{\circ} 54^{\prime}$ 221 N, 104. 50' 243 E); [V5] Ban Khom Cave, Que Phong District, $\mathrm{Pu}$ Hoat Nature Reserve (approximately $\left.19^{\circ} 54^{\prime} 221 \mathrm{~N}, 104^{\circ} 50^{\prime} 243 \mathrm{E}\right)$; [V6] Phu Nong Mount, $\mathrm{Pu}$ Mat National Park (19 $\left.01^{\prime} 340 \mathrm{~N}, 104^{\circ} 44^{\prime} 726 \mathrm{E}\right)$; [V7] a cave at Khe Mat ridge, Pu Mat National Park (approximately $19^{\circ} 01^{\prime} 340 \mathrm{~N}, 104^{\circ} 44^{\prime} 726 \mathrm{E}$ ). Twenty adult males, 13 females were collected between August 1998 and October 2008 by Pham Duc Tien, Vu Dinh Thong, Thomas Howard, and Ben Hayes. Quang Binh Province: [V8] Hoa Son Village, Ke Bang, Phong Nha National Park $\left(17^{\circ} 28^{\prime} 200 \mathrm{~N}, 105^{\circ} 31^{\prime} 200 \mathrm{E}\right)$. One adult male was collected on 18 August 1998 by Ditte Hendrichsen. Thua Thien Hue Province: [V9] Bach Ma National Park (16 $10^{\prime} 989$ N, 107 52' 496 E). Three adult males were collected between June and October 2001 by Pham Duc Tien and Vu Dinh Thong. Kon Tum Province: [V10] Chu Mom Ray National Park (14 29' $\left.021 \mathrm{~N}, 107^{\circ} 38^{\prime} 139 \mathrm{E}\right)$. Two parous females and seven nulliparous females were collected by $\mathrm{Vu}$ Dinh Thong between May and August 2005. Gia Lai Province: two sites were surveyed including [V11] Kon Cha Rang Nature Reserve $\left(14^{\circ} 17^{\prime} 400 \mathrm{~N}, 108^{\circ} 21^{\prime} 600 \mathrm{E}\right)$ and [V12] Kon Ka Kinh Nature Reserve $\left(14^{\circ} 11^{\prime} 400\right.$ N, $108^{\circ}$ $15^{\prime} 000$ E). Two males and two females were collected in March 1999 by Ben Hayes.

\section{Morphological measurements}

Multiple external and craniodental characters of each specimen were measured following Bates and Harrison (1997), Csorba et al. (2003), Furey et al. (2009), and Thomas (1997). Wet specimens were measured using a pair of dial calipers to the nearest $0.1 \mathrm{~mm}$, whereas craniodental characters were measured to the nearest 0.01 $\mathrm{mm}$ using a digital caliper under stereo microscope. Bacular morphology was also observed using a stereo microscope.

External characters measured included the following: forearm length (FA) - from the extremity of the elbow to the extremity of the carpus with the wings folded; ear length (EL) - from the lower border of the external auditory meatus to the tip of the pinna; tail length (TL) from the tip of the tail to its base adjacent to the anus; hind foot length (HF) - from the extremity of the heel behind the os calcis to the extremity of the longest digit, not including the hairs or claws; tibia length (TIB) from the knee joint to the extremity of the heel behind 
the os calcis; length of metacarpals (2MT, 3MT, 4MT, $5 \mathrm{MT}$ ) - taken from the extremity of the carpus to the distal extremity of the second, third, fourth and fifth metacarpals, respectively; length of the first and second phalanges of the third, fourth, and fifth digits (1P3D, 2P3D, 1P4D, 2P4D, 1P5D, 2P5D), respectively - taken from the proximal to the distal end of the phalanx; greatest width of nose leaf $(\mathrm{GWN})$ - greatest diameter across the horseshoe; greatest height of nose leaf (GHN) - from the base of the horseshoe to the tip of the lancet, not including the hairs.

Craniodental characters measured included the following: skull length (SL) - the greatest length from the occiput to the front of the canine; condyle-canine length (CCL) - from the exoccipital condyle to the anterior alveolus of the canine; the greatest width across the anterior lateral compartments of the rostrum (ALSW); anterior median swellings width (AMSW) - the greatest width across the median swellings in dorsal view; zygomatic width $(\mathrm{ZYW})$ - the greatest width of the skull across the zygomata; the braincase width (BW) - width of the braincase at the posterior roots of the zygomatic arches; braincase width (BW1) - the greatest width across the braincase; mastoid width (MAW) - greatest width of the braincase taken across the mastoid region; interorbital width (IOW) - the narrowest width of the interorbital constriction; palatal bridge (PB) - length of bony palate excluding the posterior spike; posterior palatal width $\left(\mathrm{M}^{3} \mathrm{M}^{3} \mathrm{~W}\right)$ - taken across the widest part of the outer borders of the third upper molar; anterior palatal width $\left(\mathrm{C}^{1} \mathrm{C}^{1} \mathrm{~W}\right)$ - taken across the widest part of the outer border of the upper canine; upper tooth row length $\left(\mathrm{CM}^{3} \mathrm{~L}\right)$ - from the front of the upper canine to the back of the crown of the third upper molar; lower tooth row length $\left(\mathrm{CM}_{3} \mathrm{~L}\right)$ - from the front of the lower canine to the back of the crown of the third lower molar; mandible length (ML) - from the most posterior part of the condyle to the most anterior part of the mandible, including the lower incisors; least height of the coronoid process $(\mathrm{CPH})$ - from the tip of the coronoid process to the apex of the indentation on the inferior surface of the ramus adjacent to the angular process.

\section{Morphometric analysis}

Statistical analyses were carried out using SPSS 16.0 (SPSS Inc., Chicago, IL, USA) and PC-ORD 5.10 (MjM Software, Gleneden Beach, OR, USA) for Windows. Descriptive statistics (minimum, maximum, mean, and standard deviation) were calculated for external and craniodental measurements. Normality of data and homogeneity of variances were explored prior to parametric $t$-tests to determine sexual dimorphism within the taxa. Non-parametric tests (Mann-Whitney U-test) were used for characters that did not show normality of data (HF, $p<0.05)$ and/or homogenous variances (ALSW, $p<0.05$ ). Multiple comparisons of characters between populations and colonies were calculated using a multivariate analysis of variance (MANOVA). Linear regression was used to examine the correlation between morphology and echolocation call frequencies. Principal component analysis (PCA) on the correlation matrix was used to discriminate between individuals. A series of $t$-test was run for morphological characters comparison between forms prior to PCA. Characters which are significant different in size $(p<0.05)$ were retained for PCA.

\section{Echolocation call recording and measurement}

Values for the frequency of maximum energy (FMAXE) for $R$. affinis in this study were largely obtained from survey work, with some additional data published by Kingsada et al. (2011) and Furey et al. (2009). Echolocation calls were recorded using a Pettersson D-240X bat detector (Pettersson Elektronik AB, Uppsala, Sweden) set in 10x time-expansion mode, and call data were stored on a digital iRiver iHP-120 Multi Codec Jukebox recorder (iriver House, Seoul, Korea). When available, a Pettersson D1000X was also used, and calls stored on a built in compact flash card (type I). The detector was set to manual recording mode with the maximum sampling rate at $768 \mathrm{kHz}$. A time expansion factor of 10 was used. Sound files were recorded and saved in 'wav' format then transferred to a laptop computer for analysis. Echolocation calls from Vietnam were recorded using the PCTape system, which was custom-made by the University of Tuebingen, Germany. Call components were displayed using spectrograms and oscillograms in BatSound Pro 3.31 (Pettersson Elektronik AB, Sweden) in which sampling frequency was $44.10 \mathrm{kHz}$; spectrograms were set as 1,024 sampling size in fast Fourier transforms with Hanning windows. The constant frequency portion of the call was selected for measuring FMAXE $(\mathrm{kHz})$ from the power spectrum feature in BatSound Pro 3.31. Multiple calls were measured for individuals where these data were available.

\section{Molecular systematics \\ Tissue collection and DNA extraction and analysis}

Tissue (liver, tongue, and wing membrane) was collected from voucher specimens and preserved in 95\% concentration ethanol. Two mitochondrial DNA (mtDNA) gene fragments were selected for analysis. A 657 base pair segment of cytochrome oxidase subunit I (COI) was sequenced at the Canadian Center for DNA Barcoding (CCDB) using standardized barcoding protocols (Ivanova et al. 2012), and a 517 base pair segment of control region (D-loop) was analyzed at the Department of Biotechnology and Molecular Biology, Prince of Songkla University, 
Thailand. For comparison, sequences from GenBank were also accessed (Table 1).

Genomic DNA was extracted using DNeasy Tissue Kits (Qiagen, Venlo, Limburg). The tRNA-proline end of mitochondrial DNA control region containing the hypervariable domain (HVI) was amplified (Chen et al. 2006) by polymerase chain reaction (PCR) using the primers DL-H 16750 (5'-CCTGAAGTAGGAA-CCA GATG-3') (Wilkison and Chapman 1991) and Thr-L 16272 (5'-CCCGGTCTTGTAAAC C-3') (Stanley et al. 1996). PCRs were carried out in $25 \mu \mathrm{l}$ volumes. Each reaction contained $7.5 \mu \mathrm{l}$ of water, $2 \mu \mathrm{l}$ of each primers (10 $\mu \mathrm{m}), 12.5 \mu \mathrm{l}$ of Top Taq Master Mix Kit (Qiagen), and 1 to $2 \mu \mathrm{l}$ of DNA template $(50 \mathrm{ng} / \mu \mathrm{l})$. The amplification was run under the thermal conditions of an initial denaturation at $95^{\circ} \mathrm{C}$ for $5 \mathrm{~min}$ followed by 34 cycles of $94^{\circ} \mathrm{C}$ for $30 \mathrm{~s}, 55^{\circ} \mathrm{C}$ for $30 \mathrm{~s}, 72^{\circ} \mathrm{C}$ for $40 \mathrm{~s}$, and a final extension cycle at $72^{\circ} \mathrm{C}$ for $10 \mathrm{~min}$. Possible contamination was checked by gel electrophoresis of $6 \mu \mathrm{l}$ of PCR reaction including a negative control (containing all reagents, but no DNA template). DNA present in a $1.5 \%$ agarose gel was stained with ethidium bromide and visualized under UV using gel analysis equipment (UVITEC, Cambridge, UK). PCR product was purified using QIA quick Gel Extraction Kit (Qiagen) before sequencing. The ABI PRISM ${ }^{\mathrm{TM}}$ Big Dye Terminator Cycle Sequencing Kit (PE Applied Biosystems, Framingham, MA, USA) was

\begin{tabular}{|c|c|}
\hline Locality & GenBank accession number \\
\hline & D-loop \\
\hline & $\begin{array}{l}\text { GQ265988, GQ265998, GQ265994-GQ265995, } \\
\text { GQ266002-GQ266003 }\end{array}$ \\
\hline & $\mathrm{COI}$ \\
\hline \multirow[t]{2}{*}{ Hunan, China } & $J F 444035$ \\
\hline & $\begin{array}{l}\text { HM541382-HM541384, HM541347-HM541351, } \\
\text { JF444036- JF444037 }\end{array}$ \\
\hline Myanmar & HM541326 \\
\hline Xiangkhoang, Lao & HM541341 \\
\hline \multirow[t]{2}{*}{ Vientiane, Lao } & HM541366-HM541367 \\
\hline & $\begin{array}{l}\text { HM541364, HM541403-HM541406, } \\
\text { HM541398-HM541400 }\end{array}$ \\
\hline \multirow[t]{3}{*}{ Lao Cai, Vietnam } & HQ580330-HQ580331 \\
\hline & HM541401-HM541402, HM541395 \\
\hline & $\begin{array}{l}\text { HM541396-HM541397, JF444039-JF444043, } \\
\text { GU684791-GU684794, GU684798, GU694801 }\end{array}$ \\
\hline Pahang, Malaysia & HM541330 \\
\hline $\begin{array}{l}\text { Negeri Sembilan, } \\
\text { Malaysia }\end{array}$ & HM541331-HM541332 \\
\hline Johor, Malaysia & HM541407-HM541414 \\
\hline
\end{tabular}

used to prepare the DNA samples for sequence analysis. Sequencing was performed on an ABI Prism 310 Genetic Analyzer (PE Applied Biosystems, Framingham, MA, USA). The chromatograms were edited using Geneious Pro 5.6 trial version and BIOEDIT 7.0.0 (Hall 1999) and aligned using CLUSTAL_X 1.83 (Thompson et al. 1997) and MEGA 5.2.2 (Tamura et al. 2011).

Phylogenetic relationships among sequences were reconstructed for each gene separately using maximumlikelihood in the program MEGA 5.2.2 (Tamura et al. 2011). The most appropriate substitution model was determined using BIC as implemented in jModel Test 2.14 (Darriba et al. 2012). Among the 88 models in the 100\% confidence interval, the Hasegawa-Kishino-Yano substitution model (HKY) with proportion of invariant sites (I) was the best-fit model selected for D-loop and Kimura 2-parameter (K80) was the best-fit model for COI. We also performed Bayesian Analysis for each gene separately using Mr Bayes 3.2.2 (Huelsenbeck and Ronquist 2001). In Bayesian Analysis, convergence stationarity was searched by two independent metropolis-coupled Markov chain Monte Carlo (MCMC), each comprising three incrementally heated chains and one cold chain, run for six million generations, with parameters sampled every 1,000 generations. Convergence stationary of the MCMC chains was evaluated by inspecting whether the standard deviation of split frequencies approached zero and the potential scale reduction factor (PSRF) reached 1.0 for all parameters. We also investigated the convergence using Tracer 1.5 (Rambaut and Drummond 2009), and the 25\% initial phase of the Markov chain was discarded as a burn-in. A congeneric $R$. pearsoni (GenBank accession number JN106201) was used as an out group in the phylogenetic analysis of D-loop in order to examine the monophyletic lineage of $R$. affinis.

To estimate the time to the most recent common ancestor (TMRCA) among the observed clades, D-loop was analyzed in BEAST version 1.8 (Rambaut and Drummond 2007). The gene was selected for the analysis as its divergence rate is known and has been used in previous publications (Mao et al. 2010; Chen et al. 2006; Salgueiro et al. 2004). Based on jModel test, HKY $+\mathrm{I}$ was selected as the best substitution model and relaxed-clock model with an uncorrelated lognormal distribution was used to estimate the substitution rate. We performed two independent runs of MCMC chains with 60 million generation each with parameters logged every 1,000 generation. Tracer version 1.5 (Rambaut and Drummond 2009) was used to combine the two runs as well as to examine the effective sample size (ESS) for the parameters. Trees were collated using Tree Annotator version 1.8 where the maximum clade credibility tree and Median heights were selected; and 10\% (6,000 trees) of the sample trees were selected as burn-in. To convert 
the estimates scaled by mutation rate to calendar years, we used the divergence rate of $20 \% / \mathrm{Myr}$ for control region which was previously calibrated in the noctule bat (Petit et al. 1999) and used in R. affinis (Mao et al. 2010) and other bats (Chen et al. 2006; Salgueiro et al. 2004).

\section{Results}

\section{Morphometric}

External and cranial measurements were available for 170 specimens. No significant size differences in means $(p>0.05)$ in 34 external and cranial characters were observed between the sexes (Table 2). A total of 28 external and cranial characters were retained for multivariate analysis. A multivariate analysis (PCA) using these 28 external and cranial characters from the total 168 specimens (two specimens were excluded from PCA due to the incomplete measurements) from continental Southeast Asia formed two relatively distinct groups (Figure 2). These represent the two recognized zoogeographic subregions (Indochinese subregion and Sundaic subregion) and correspond to $R$. a. macrurus and $R$. a. superans, respectively. Based on the 28 external and cranial characters analyzed, northern Cambodian specimens largely overlap with the Sundaic group (Figure 2). However, a further PCA performed on 18 selected characters (based on $t$-test), separated this population from the Peninsula group (Figure 3).

In the Indochinese subregion, specimens have significantly larger forearm and wing measurements $(p<0.001$ for most characters). The tail and hind foot are also longer, but the horseshoe is significantly smaller $(p<0.05)$ ( $p$ values were not included; see Table 3 for size comparison). In terms of skull characters, this population is significantly smaller $(p<0.001$ for most characters) compared to individuals from the Sundaic subregion. Sundaic specimens generally have a broader cranial dimensions and larger rostral chambers. Additionally, the anterior lateral swellings, anterior median swellings, and posterior median swellings are more enlarged.

Fifty-one bacula (27 bacula from Sundaic subregion, 24 from Indochinese subregion) were extracted for examination. All bacula observed were symmetrical (in dorsal view and ventral views), the basal part being bulbous with a long slender curved shaft. The basal portion is typically emarginated in the dorsal view and lateral views, with the dorsal aspect more compressed than the ventral aspect. Bacular characters showed a relatively divergent pattern between zoogeographic subregions with specimens from the Indochinese subregion (including Cambodia, Vietnam, and central Myanmar) having a smaller and more curved shaft, while Sundaic specimens have a larger and straighter shafted baculum (Figure 4A,B,C). The Indochinese population generally has shorter and smaller-sized bacula, characterized by a bulbous and more rounded basal portion abruptly depressed to a slender shaft (Figure 4B,C). The shaft is more curved, slender to the tip with no enlargedportion at the tip of the shaft (Figure 4B,C). The basal portion is broader and deeper in dorsal view. In Sundaic specimens, bacula are generally longer with less curved shafts (Figure 4A). The basal portion is broader and more elongated, gradually becoming slender at the tip which is rather pointed and typically shows enlargement characteristic of specimens from the Sundaic region (15 of the 19 bacula from the Thai Peninsula have this character). The emargination of the basal portion in the dorsal view is not obvious, being mostly narrow and shallow, while ventral emargination is comparable to those from Indochinese subregion (Figure 4A).

\section{Echolocation}

In total, 47 echolocation calls were available from 21 localities in Cambodia, Thailand, and Vietnam. These comprised 33 calls recorded from 12 localities in the current study and 14 calls published in Kingsada et al. (2011). In total, five calls were excluded from the analysis as they were all from male individuals from the same locality. As such, a $t$-test was run on 42 calls (29 males, 13 females) from the central Thai Peninsula. No significant variation in call frequency was found between the sexes $(p=0.932)$, the table of comparison was not included.

Correlations between peak call frequency (FMAXE) and size were explored. No correlation was found between FA and FMAXE $(y=0.010 \mathrm{x}+73.064, r=0.004, P=0.978)$. However, a significant negative relationship was found between skull size (SL, $y=-3.789 \mathrm{x}+158.839, r=0.400$, $P<0.002$; CCL, $y=-6.476 \mathrm{x}+202.112, r=0.629, P=0.001$ ) and sound generating organs and chambers (GWN, $y=-4.319 \mathrm{x}+116.610, r=0.731, P=0.001$; ALSW, $y=-9.493 \mathrm{x}+131.790, r=0.544, P=0.002$; AMSW, $y=-6.142 \mathrm{x}+99.649, r=0.394, P<0.002)$.

Call frequency showed considerable variation throughout the region, ranging from 69 to $84 \mathrm{kHz}$. Four call frequency zones were designated; $\mathrm{A}=$ Indochinese low frequency (69 to $74 \mathrm{kHz}$ ) (upper northern Vietnam and low south China); B = Indochinese high frequency (75 to $84 \mathrm{kHz}$ ) (northern Thailand down to southern Vietnam, Cambodia and upper peninsular Thailand) (Table 4 and Figure 5); $\mathrm{C}=$ Sundaic low frequency (69 to $72 \mathrm{kHz}$ ) (Songkhla up to Chumphon); D = Sundaic high frequency (77 to $78 \mathrm{kHz}$ ) (Thai-Malay border down peninsular Malaysia). A mixture of low and high call frequencies (69 to $76 \mathrm{kHz}$ ) were recorded from zone $\mathrm{C}$, around Chumphon and Ranong Provinces between $9^{\circ}$ to $11^{\circ} \mathrm{N}$ (Figure 5).

\section{Genetic}

In total, 26 sequences of hyper-variable gene (control region) (GenBank accession number: KP192696-KP192721) 
Table 2 Morphometric comparison between male and female of $\boldsymbol{R}$. affinis from Thailand, Myanmar, and Vietnam

\begin{tabular}{|c|c|c|c|c|c|c|c|c|c|c|c|c|}
\hline$n$ & Sex & FA & $\mathrm{HB}$ & TL & $\mathrm{EL}$ & TIB & $\mathrm{HF}$ & $2 \mathrm{MT}$ & 3MT & $4 \mathrm{MT}$ & $5 \mathrm{MT}$ & 3D1P \\
\hline \multirow[t]{2}{*}{39} & 우우 & $51.3 \pm 1.7$ & $51.7 \pm 2.4$ & $24.0 \pm 2.6$ & $22.2 \pm 1.4$ & $24.3 \pm 0.9$ & $10.50 \pm 0.4$ & $41.7 \pm 1.4$ & $39.1 \pm 1.3$ & $40.2 \pm 1.3$ & $40.8 \pm 1.5$ & $15.2 \pm 0.6$ \\
\hline & & 48.3 to 54.8 & 46.5 to 59.1 & 19.3 to 29.3 & 19.7 to 25.4 & 22.2 to 26.4 & 9.4 to 11.2 & 39.4 to 44.5 & 36.8 to 42.4 & 37.6 to 42.8 & 38.1 to 44.0 & 13.7 to 16.6 \\
\hline \multirow[t]{2}{*}{60} & $\hat{\partial} \hat{o}$ & $51.0 \pm 1.5$ & $52.1 \pm 2.8$ & $23.3 \pm 2.4$ & $21.9 \pm 1.1$ & $24.3 \pm 1.0$ & $10.3 \pm 0.5$ & $41.3 \pm 1.4$ & $38.8 \pm 1.4$ & $39.9 \pm 1.4$ & $40.5 \pm 1.4$ & $15.0 \pm 0.6$ \\
\hline & & 48.3 to 54.4 & 42.7 to 57.8 & 18.8 to 30.7 & 19.6 to 25.8 & 21.8 to 26.0 & 9.0 to 11.3 & 38.3 to 44.7 & 35.7 to 43.0 & 36.7 to 43.5 & 37.7 to 44.5 & 13.7 to 16.5 \\
\hline Sex. dim. & & ns & ns & ns & ns & ns & ns & ns & ns & ns & ns & ns \\
\hline$n$ & Sex & $3 \mathrm{D} 2 \mathrm{P}$ & $4 \mathrm{D} 1 \mathrm{P}$ & $4 \mathrm{D} 2 \mathrm{P}$ & $5 \mathrm{D} 1 \mathrm{P}$ & $5 \mathrm{D} 2 \mathrm{P}$ & GHN & GWN & & & & \\
\hline \multirow[t]{2}{*}{39} & 우우 & $25.9 \pm 1.5$ & $10.4 \pm 0.4$ & $15.4 \pm 0.8$ & $11.8 \pm 0.5$ & $13.7 \pm 1.3$ & $13.6 \pm 1.0$ & $9.9 \pm 0.6$ & & & & \\
\hline & & 18.3 to 27.9 & 9.7 to 11.5 & 13.5 to 17.2 & 10.7 to 12.9 & 9.0 to 15.5 & 10.4 to 15.6 & 8.3 to 11.1 & & & & \\
\hline \multirow[t]{2}{*}{60} & ถึ่ & $26.1 \pm 1.2$ & $10.3 \pm 0.4$ & $15.4 \pm 0.8$ & $11.7 \pm 0.6$ & $13.6 \pm 1.0$ & $13.8 \pm 0.9$ & $9.9 \pm 0.5$ & & & & \\
\hline & & 23.5 to 30.0 & 9.5 to 11.4 & 13.8 to 17.6 & 10.5 to 13.2 & 9.6 to 15.8 & 11.8 to 16.1 & 8.5 to 11.2 & & & & \\
\hline Sex. dim. & & ns & ns & ns & ns & ns & ns & ns & & & & \\
\hline$n$ & & $S L$ & $\mathrm{CCL}$ & ZYW & MAW & BW & ALSW & AMSW & IOW & & & \\
\hline \multirow[t]{2}{*}{39} & & $22.55 \pm 0.4$ & $19.90 \pm 0.3$ & $11.22 \pm 0.2$ & $10.58 \pm 0.2$ & $10.19 \pm 0.1$ & $6.07 \pm 0.1$ & $4.22 \pm 0.1$ & $2.18 \pm 0.2$ & & & \\
\hline & & 21.92 to 23.53 & 19.11 to 20.68 & 10.80 to 11.87 & 10.17 to 11.15 & 9.89 to 10.60 & 5.65 to 6.36 & 3.81 to 4.72 & 1.72 to 2.60 & & & \\
\hline \multirow[t]{2}{*}{60} & & $22.55 \pm 0.4$ & $19.89 \pm 0.4$ & $11.21 \pm 0.2$ & $10.63 \pm 0.2$ & $10.18 \pm 0.2$ & $6.12 \pm 0.2$ & $4.20 \pm 0.2$ & $2.27 \pm 0.2$ & & & \\
\hline & & 21.47 to 23.33 & 18.78 to 20.78 & 10.53 to 11.91 & 9.81 to 11.16 & 9.54 to 10.67 & 5.56 to 6.72 & 3.59 to 4.67 & 1.70 to 2.81 & & & \\
\hline Sex. dim. & & ns & ns & ns & ns & ns & ns & ns & $P=0.047$ & & & \\
\hline$n$ & & $\mathrm{~PB}$ & $C M^{3} L$ & $C^{1} C^{1} W$ & $M^{3} M^{3} W$ & $M L$ & $\mathrm{CM}_{3} \mathrm{~L}$ & $\mathrm{CPH}$ & & & & \\
\hline \multirow[t]{2}{*}{39} & & $2.15 \pm 0.1$ & $8.91 \pm 0.1$ & $5.75 \pm 0.1$ & $8.20 \pm 0.1$ & $15.48 \pm 0.2$ & $9.33 \pm 0.1$ & $3.13 \pm 0.1$ & & & & \\
\hline & & 1.82 to 2.67 & 8.53 to 9.34 & 5.23 to 6.05 & 7.77 to 8.86 & 14.91 to 15.96 & 8.98 to 9.74 & 2.52 to 3.42 & & & & \\
\hline \multirow[t]{2}{*}{60} & & $2.19 \pm 0.1$ & $8.96 \pm 0.2$ & $5.79 \pm 0.1$ & $8.23 \pm 0.2$ & $15.51 \pm 0.3$ & $9.34 \pm 0.2$ & $3.14 \pm 0.1$ & & & & \\
\hline & & 1.63 to 2.61 & 8.36 to 9.38 & 5.22 to 6.13 & 7.73 to 8.72 & 14.59 to 16.07 & 8.75 to 9.82 & 2.86 to 3.63 & & & & \\
\hline Sex. dim. & & ns & ns & ns & ns & ns & ns & ns & & & & \\
\hline
\end{tabular}

External and craniodental measurements are in mm. FA - forearm length; HB - head and body length; TL - tail length; EL - ear length; TIB - tibia length; HF - hind foot length; 2MT, 3MT, 4MT, 5MT - second, third, fourth, and fifth metacarpal lengths; 3D1P, 3DP2P, 4D1P, 4D2P, 5D1P, 5D2P - first and second phalanges of third, fourth, and fifth digits; GHN - great high of nose leaf; GWN - great width of nose leaf; SL - skull length;

CCL - condyle-canine length; ZYW - zygomatic width; BW - braincase width; MAW - mastoid width; ALSW - anterior lateral swellings width; AMSW - anterior median swellings width; IOW - inter-orbital width; PB - palatal bridge; $\mathrm{CM}^{3} \mathrm{~L}$ - upper tooth row length; $\mathrm{C}^{1} \mathrm{C}^{1} \mathrm{~W}$ - anterior palatal width; $\mathrm{M}^{3} \mathrm{M}^{3} \mathrm{~W}$ - posterior palatal width, $\mathrm{ML}$ - mandible length; $\mathrm{CM}_{3} \mathrm{~L}$ - lower tooth row length; $\mathrm{CPH}$ - least height of the coronoid process. Data are displayed in mean \pm standard deviation and range. Sex. dim.=sexual dimorphism; ns=not significant. 


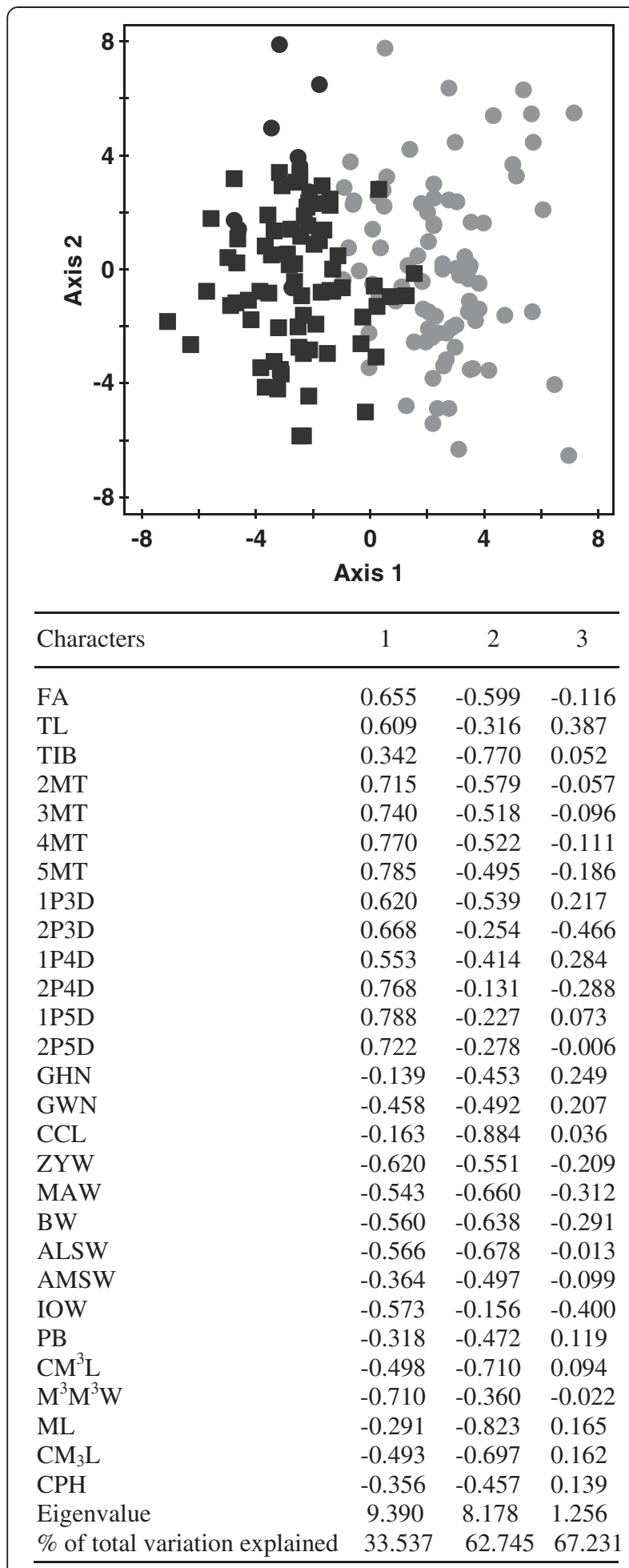

Figure 2 Principal component analysis (PCA) of 28 external and cranial characters. The morphological comparison between

Sundaic subregion (square) and Indochinese subregion (circle). Black circles are specimens from northern Cambodia and eastern Thailand which largely overlapped with Sundaic specimens.

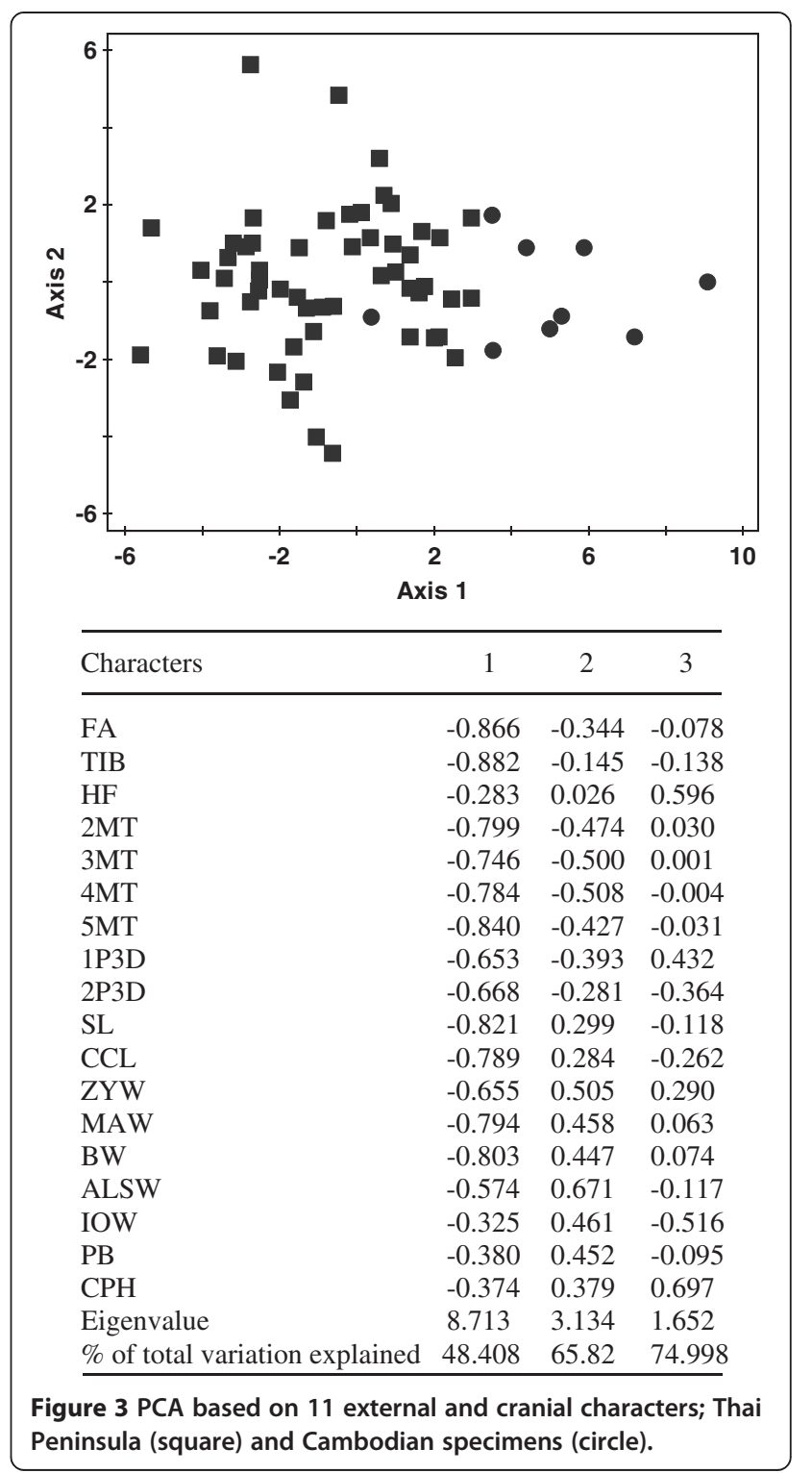

and 16 sequences of COI [GenBank accession number: KP192673-KP192688] were available for genetic analysis.

Results from both maximum likelihood (ML) and Bayesian analysis (BA) showed similar topologies. For both genes analyzed, three well-supported clades were recovered, clade i, I and ii, II (D-loop and COI), and clade III (COI) (Figures 6 and 7). Clade i and I comprised of all sequences from the peninsular region including peninsular Thailand, peninsular Malaysia, and peninsular Myanmar, and was therefore defined as the Sundaic clade, representing $R$. a. superans. Clade ii, II, and III comprised sequences from Indochinese subregion including northern Thailand, central Myanmar, Cambodia, Laos, Vietnam, and southern China, and these combined were defined as the Indochinese clade, representing $R$. a. macrurus. Clade ii and II comprised 
Table 3 Morphometric comparison between recognized forms within mainland Southeast Asia

\begin{tabular}{|c|c|c|c|c|c|c|c|c|c|c|c|c|}
\hline$n$ & Sex & FA & HB & $\mathrm{TL}$ & EL & TIB & $\mathrm{HF}$ & $2 \mathrm{MT}$ & 3MT & 4MT & 5MT & 3D1P \\
\hline \multicolumn{13}{|c|}{ Rhinolophus a. tener Holotype } \\
\hline 1 & $\hat{\partial} \hat{o}$ & 49.3 & - & $23.00^{\mathrm{a}}$ & 18.85 & 23.85 & 11.51 & - & 37.04 & 38.02 & 39.33 & 14.77 \\
\hline \multicolumn{13}{|c|}{ Rhinolophus a. macrurus Holotype } \\
\hline 1 & $\hat{\partial} \bar{O}$ & 53.03 & - & - & - & 24.76 & 11.60 & - & 40.94 & 41.86 & 42.82 & 16.67 \\
\hline \multicolumn{13}{|c|}{ R. a. macrurus-form A } \\
\hline \multirow[t]{2}{*}{9} & q⿳亠丷厂 & $47.8 \pm 1.4$ & $53.8 \pm 1.8$ & $23.0 \pm 1.7$ & $21.2 \pm 1.6$ & $21.9 \pm 1.0$ & $9.7 \pm 0.5$ & $39.3 \pm 0.7$ & $37.0 \pm 1.0$ & $37.7 \pm 1.0$ & $38.0 \pm 1.1$ & $14.1 \pm 0.4$ \\
\hline & & 45.7 to 50.0 & 51.3 to 7.1 & 20.4 to 25.1 & 18.4 to 23.3 & 19.4 to 22.9 & 8.8 to 10.7 & 38.3 to 40.9 & 35.5 to 39.0 & 36.4 to 39.6 & 36.6 to 40.2 & 13.4 to 14.7 \\
\hline \multicolumn{13}{|c|}{ R. a. macrurus-form B } \\
\hline \multirow[t]{2}{*}{14} & q⿳亠丷厂 & $52.6 \pm 0.8$ & $49.7 \pm 1.9$ & $24.0 \pm 1.5$ & $20.3 \pm 1.0$ & $23.2 \pm 0.6$ & $10.4 \pm 0.2$ & $42.4 \pm 0.8$ & $40.5 \pm 1.0$ & $41.6 \pm 1.0$ & $42.4 \pm 0.6$ & $15.0 \pm 0.4$ \\
\hline & & 50.6 to 54.2 & 45.7 to 52.3 & 22.0 to 27.7 & 18.4 to 21.9 & 21.7 to 23.8 & 10.0 to 11.0 & 41.0 to 44.3 & 39.3 to 43.7 & 40.3 to 44.3 & 41.5 to 43.3 & 14.3 to 15.9 \\
\hline \multicolumn{13}{|c|}{ R. a. macrurus-form C } \\
\hline \multirow[t]{2}{*}{60} & qै人 & $52.2 \pm 1.4$ & $52.2 \pm 2.6$ & $25.8 \pm 2.2$ & $22.4 \pm 1.3$ & $24.9 \pm 0.8$ & $10.4 \pm 0.5$ & $42.5 \pm 1.4$ & $40.0 \pm 1.3$ & $41.2 \pm 1.2$ & $41.8 \pm 1.2$ & $15.6 \pm 0.6$ \\
\hline & & 48.3 to 55.9 & 42.7 to 59.1 & 20.3 to 30.7 & 19.7 to 25.8 & 22.5 to 27.2 & 9.0 to 11.6 & 38.6 to 46.1 & 36.2 to 43.0 & 37.9 to 44.3 & 38.9 to 44.8 & 14.3 to 17.8 \\
\hline \multicolumn{13}{|c|}{ R. a. macrurus-form C-central Vietnam } \\
\hline \multirow[t]{2}{*}{18} & qổ & $50.6 \pm 1.1$ & $52.5 \pm 2.7$ & $23.7 \pm 3.2$ & $21.2 \pm 0.9$ & $23.6 \pm 0.8$ & $10.5 \pm 0.2$ & $41.5 \pm 0.9(17)$ & $38.9 \pm 1.0(17)$ & $40.1 \pm 0.9(17)$ & $41.0 \pm 1.0(17)$ & $15.2 \pm 0.6(17)$ \\
\hline & & 49.0 to 53.2 & 48.2 to 57.5 & 17.5 to 27.5 & 19.0 to 22.7 & 21.7 to 25.0 & 10.1 to 11.0 & 39.9 to 43.2 & 37.3 to 41.1 & 38.4 to 41.9 & 39.4 to 43.4 & 14.1 to 16.1 \\
\hline \multicolumn{13}{|c|}{ Rhinolophus a. superans Holotype } \\
\hline 1 & 우 & 50.97 & - & - & 20.36 & 25.35 & 11.66 & - & 39.52 & 40.67 & 41.45 & 15.10 \\
\hline \multicolumn{13}{|c|}{ R. a. superans-Thai Peninsula } \\
\hline \multirow[t]{2}{*}{66} & 우우 & $50.6 \pm 1.2$ & $51.9 \pm 2.4$ & $22.1 \pm 1.6$ & $21.6 \pm 1.1$ & $24.2 \pm 0.8$ & $10.5 \pm 0.5$ & $40.9 \pm 1.1$ & $38.4 \pm 1.0$ & $39.4 \pm 1.0$ & $40.0 \pm 1.0$ & $14.9 \pm 0.6$ \\
\hline & & 48.3 to 52.9 & 46.9 to 57.8 & 18.8 to 25.8 & 18.4 to 24.4 & 22.4 to 26.4 & 8.5 to 11.6 & 38.5 to 44.0 & 35.7 to 40.3 & 37.1 to 42.0 & 38.1 to 42.3 & 13.7 to 16.5 \\
\hline$n$ & Sex & $3 \mathrm{D} 2 \mathrm{P}$ & 4D1P & $4 \mathrm{D} 2 \mathrm{P}$ & $5 \mathrm{D} 1 \mathrm{P}$ & $5 \mathrm{D} 2 \mathrm{P}$ & $\mathrm{GHN}$ & GWN & & & & \\
\hline \multicolumn{13}{|c|}{ Rhinolophus a. tener Holotype } \\
\hline 1 & $\hat{\partial} \hat{O}$ & 25.32 & - & - & - & - & $13.8^{\mathrm{a}}$ & $9.50^{\mathrm{a}}$ & & & & \\
\hline \multicolumn{13}{|c|}{ Rhinolophus a. macrurus Holotype } \\
\hline 1 & $\hat{0} \overline{0}$ & 26.69 & - & - & - & - & - & - & & & & \\
\hline \multicolumn{13}{|c|}{ R. a. macrurus-form A } \\
\hline \multirow[t]{2}{*}{9} & 우 & $24.6 \pm 0.87$ & $10.0 \pm .1$ & $14.4 \pm 0.6$ & $11.4 \pm 0.4$ & $13.4 \pm 0.5$ & $13.6 \pm 0.7$ & $10.0 \pm 0.2$ & & & & \\
\hline & & 23.7 to 26.2 & 9.8 to 10.4 & 13.0 to 15.0 & 10.8 to 12.0 & 12.6 to 14.4 & 12.7 to 14.7 & 9.8 to 10.5 & & & & \\
\hline \multicolumn{13}{|c|}{ R. a. macrurus-form B } \\
\hline \multirow[t]{2}{*}{14} & q0ิ & $28.1 \pm 1.0$ & $10.3 \pm 0.4$ & $17.2 \pm .3$ & $12.6 \pm 0.4$ & $14.0 \pm .3$ & $12.6 \pm 0.8(13)$ & $8.2 \pm 0.4$ & & & & \\
\hline & & 26.5 to 29.8 & 9.8 to 11.3 & 16.7 to 18.0 & 12.0 to 13.4 & 13.5 to 14.5 & 11.0 to 13.8 & 7.5 to 9.0 & & & & \\
\hline
\end{tabular}


Table 3 Morphometric comparison between recognized forms within mainland Southeast Asia (Continued)

R. a. macrurus-form $\mathrm{C}$

60 오숭 $26.7 \pm 1.1$

23.5 to 29.0

$10.7 \pm 0.5$

$16.1 \pm 0.8$

$12.2 \pm 0.5$

$14.7 \pm 0.8$

$13.8 \pm 0.8$

$9.7 \pm 0.5$

R. a. macrurus-form C-central Vietnam
17 우 $27.3 \pm 1.0 \quad 10.5 \pm 0.6$

$$
25.1 \text { to } 30.0 \quad 9.7 \text { to } 11.90
$$

$16.4 \pm 0.6$

\begin{abstract}
$12.2 \pm 0.5$
\end{abstract}
12.7 to 16.3

11.8 to 16.1

8.3 to 11.2

Rhinolophus a. superans Holotype

$$
1 \quad \text { 우우 } 25.38
$$

R. a. superans-Thai Peninsula

$\begin{array}{llll}66 & \text { 워 } & 25.7 \pm 0.8 & 10.3 \pm 0.5 \\ & & 23.8 \text { to } 27.7 & 9.2 \text { to } 11.5 \\ n & \text { Sex } & \text { SL } & \text { CCL }\end{array}$

Rhinolophus a. tener Holotype

$\begin{array}{llll}1 & \text { oे } & 21.34 & 18.80\end{array}$

Rhinolophus a. macrurus Holotype

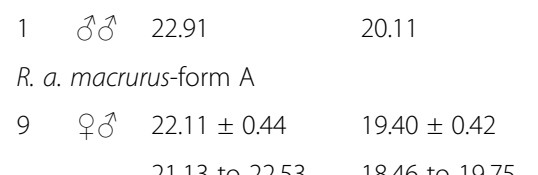

$14.9 \pm 0.8$
11.2 to 16.3
ZYWW

$11.5 \pm 0.5$

10.6 to 12.6

MAW

$13.1 \pm 0.7$

9.6 to 14.6

BW

$14.0 \pm 0.9$
10.4 to 15.9
BW1

$10.0 \pm 0.5(63)$

$$
-
$$

8.83

11.38

10.78

$11.05 \pm 0.25$

$10.30 \pm 0.16$

21.13 to 22.53

10.69 to 11.51

10.04 to 10.55

$9.99 \pm 0.20$

9.77 to 10.38

$9.40 \pm 0.06$

9.27 to 9.49

R. a. macrurus-form B

$$
\begin{array}{llll}
8 & \text { †시 } & 21.77 \pm .21 & 19.07 \pm 0.19 \\
& 21.52 \text { to } 22.08 & 18.85 \text { to } 19.37
\end{array}
$$

$10.71 \pm 0.24$

$10.14 \pm 0.14$

$9.77 \pm 0.12$

$9.18 \pm 0.15$

9.01 to 9.42

$5.44 \pm 0.11$

9.54 to 9.95

R. a. macrurus-form C

60 우 $22.64 \pm 0.38 \quad 19.94 \pm 0.37$ 21.47 to $23.40 \quad 18.78$ to 20.64

\title{
$11.08 \pm 0.20 \quad 10.47 \pm 0.20 \quad 10.06 \pm 0.16$
}

10.53 to $11.49 \quad 9.81$ to 11.15

9.54 to 10.57

$9.41 \pm 0.20$

9.00 to 9.85

$6.01 \pm 0.16$

5.63 to 6.35

$1.17 \pm 0.18$

3.70 to 4.72

R. a. macrurus-form C-central Vietnam

\begin{abstract}
19 우우 $22.02 \pm 0.21(17) \quad 19.34 \pm 0.20(17)$
21.61 to $22.35 \quad 18.96$ to 19.78

Rhinolophus a. superans Holotype
\end{abstract}

$\begin{array}{ll}11.03 \pm 0.15 & 10.38 \pm 0.15 \\ 10.78 \text { to } 11.34 & 10.15 \text { to } 10.64\end{array}$

$10.03 \pm 0.10$

$9.49 \pm 0.13$

$5.81 \pm 0.12$

$4.07 \pm 0.10$

$2.20 \pm 0.14$

$\begin{array}{llll}1 & \text { 우우 } & 22.38 & 19.65\end{array}$

11.32

10.84

9.41

5.60

3.71 
Table 3 Morphometric comparison between recognized forms within mainland Southeast Asia (Continued)

R. a. superans-Thai Peninsula

$\begin{array}{lllllllllll}66 & \text { 우 } & 22.51 \pm 0.40 & 19.87 \pm 0.37 & 11.37 \pm 0.22 & 10.76 \pm 0.18(65) & 10.32 \pm 0.20 & 9.77 \pm 0.20 & 6.15 \pm 0.19 & 4.26 \pm 0.21 & 2.35 \pm 0.17 \\ & 21.59 \text { to } 23.27 & 19.08 \text { to } 20.78 & 10.84 \text { to } 11.91 & 10.39 \text { to } 11.16 & 9.80 \text { to } 10.67 & 9.27 \text { to } 10.14 & 5.82 \text { to } 6.72 & 3.76 \text { to } 4.67 & 2.00 \text { to } 2.81 \\ n & \text { Sex } & \text { PB } & \mathrm{CM}^{3} \mathrm{~L} & \mathrm{C}^{1} \mathrm{C}^{1} \mathrm{~W} & \mathrm{M}^{3} \mathrm{M}^{3} \mathrm{~W} & \mathrm{ML} & \mathrm{CM} \mathrm{M}_{3} \mathrm{~L} & \mathrm{CPH} & \end{array}$

Rhinolophus a. tener Holotype
1 ठิठ 2.22

8.52

5.51

8.26

15.04

9.00

Rhinolophus a. macrurus Holotype

1 ठิす 2.42

9.01

5.77

8.76

15.92

9.67

a. macrurus-form $A$

9 ô $2.09 \pm 0.11$

\begin{abstract}
1.94 to 2.28
\end{abstract}
$8.91 \pm 0.20$

$5.74 \pm 0.37$

$8.36 \pm .28$

$15.40 \pm 0.35$

$9.3 \pm 0.23$

5.27 to 6.35

7.90 to 8.74

14.81 to 15.95

8.94 to 9.65

$3.06 \pm .09$

R. a. macrurus-form $B$

8 웅 $1.89 \pm 0.15$

1.70 to 2.20

$8.46 \pm 0.15$

$5.56 \pm 0.19$

$7.78 \pm 0.18$

$14.71 \pm 0.12$

$8.80 \pm 0.18$

2.95 to 3.21

R. a. macrurus-form C

60 우 $2.17 \pm 0.15$

8.20 to 8.69

5.26 to 5.84

7.56 to 8.03

14.57 to 14.90

8.53 to 9.06

$2.93 \pm 0.06$

2.83 to 3.06
1.89 to 2.67

$8.87 \pm 0.19$

$5.79 \pm 0.18$

$8.06 \pm 0.15$

$15.5 \pm 0.23$

$9.27 \pm 0.19$

$3.12 \pm 0.15$

R. a. macrurus-form C-central Vietnam
19 우으 $2.04 \pm 0.18$
$8.67 \pm 0.11$
1.63 to 2.52
8.45 to 8.87

$5.74 \pm 0.18$

$8.05 \pm 0.14$

$15.10 \pm 0.18$

$9.08 \pm 0.11$

$3.03 \pm 0.11(18)$

5.21 to 5.99

7.77 to 8.33

14.70 to 15.50

8.87 to 9.31

2.83 to 3.29

Rhinolophus a. superans Holotype

1 우 263

R. a. superans-Thai Peninsula
66 우으 $2.22 \pm 0.13$
$8.99 \pm 0.19$
1.89 to 2.61
8.48 to 9.38
$5.78 \pm 0.17(65) \quad 8.34 \pm 0.18(65)$
$15.51 \pm 0.30(65)$
$9.41 \pm 0.20$
$3.18 \pm 0.14$
5.23 to $6.20 \quad 7.92$ to 8.86
14.79 to 16.07
9.03 to 9.82
2.87 to 3.63

5.66

8.46

15.52

External and craniodental measurements are in mm; FA - forearm length; HB - head and body length; TL - tail length; EL - ear length; TIB - tibia length; HF - hind foot length; 2MT, 3MT, 4MT, 5MT - second, third, fourth and fifth metacarpal lengths; 3D1P, 3DP2P, 4D1P, 4D2P, 5D1P, 5D2P - first and second phalanges of third, fourth, and fifth digits; GHN - great high of nose leaf; GWN - great width of nose leaf; SL - skull length;

CCL - condyle-canine length; ZYW - zygomatic width; BW - braincase width; BW1 - braincase width; MAW - mastoid width; ALSW - anterior lateral swellings width; AMSW - anterior median swellings width;

IOW - inter-orbital width; $\mathrm{PB}$ - palatal bridge; $\mathrm{CM}^{3} \mathrm{~L}$ - upper tooth row length; $\mathrm{C}^{1} \mathrm{C}^{1} \mathrm{~W}$-anterior palatal width; $\mathrm{M}^{3} \mathrm{M}^{3} \mathrm{~W}$ - posterior palatal width, $\mathrm{ML}$ - mandible length; $C \mathrm{M}_{3} \mathrm{~L}$ - lower tooth row length; $C P \mathrm{CP}$ - least height of the coronoid process. Data are displayed in mean \pm standard deviation and range. Sample size is placed in parentheses when different to $n$, a Values based on literature. 


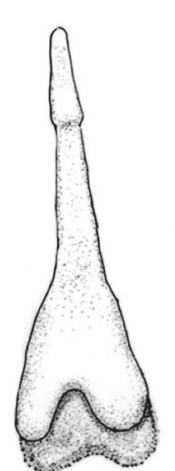

A

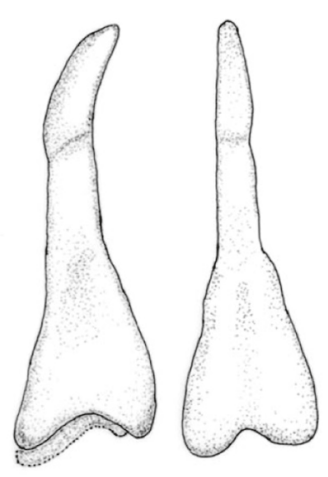

$5 \mathrm{~mm}$
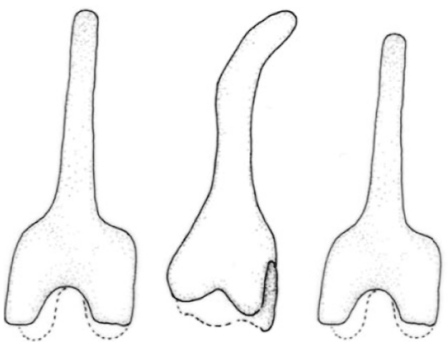

$\mathrm{B}$

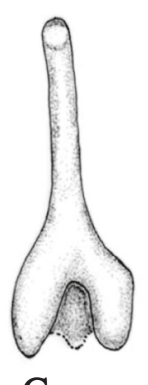

$\mathrm{C}$
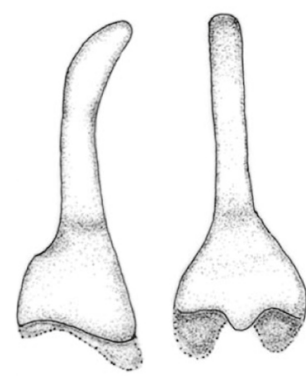

$1 \mathrm{~mm}$

Figure 4 Baculum morphology of $R$. a. superans (A) and R. a. macrurus (B, C). (A) Specimen from Songkhla, central peninsular Thailand, (B) specimen from Siem Reap, north-western Cambodia, and (C) specimen from Chiang Mai, northern Thailand).

sequences from northern Vietnam (Hoang Lien Son and Vinh Phuc), northern Lao (Vientiane and Xiangkhouang), northern Thailand (Chiang Mai), central Myanmar (Shan), north-western Cambodia (Siem Reap), southern Vietnam (Thua Thien-Hue and Kon Tum) and lower southern
China (Guangxi) while clade III comprised sequences which broadly overlapped geographically with clade ii and II, comprising sequences from southern Vietnam (Lam Dong and Quang Nam), northern Vietnam (Hoang Lien Son and Lao Cai) and upper southern China (Hunan)

Table 4 The summary data for frequency maximum energy (FMAXE) of $\boldsymbol{R}$. affinis from mainland Southeast Asia

\begin{tabular}{|c|c|c|c|c|}
\hline Locality and echolocation zone & Number bats & Number calls & Frequency (kHz) & Source \\
\hline Northern Vietnam & & 13 & $72.1 \pm 0.9$ & Current study and Furey et al. (2009) \\
\hline Zone A & & & 71.4 to 73.4 & \\
\hline \multirow[t]{2}{*}{ Southern Vietnam } & 3 & 36 & $81.9 \pm 0.23$ & O'Shea and Gore (2011) (personal communications) \\
\hline & & & 81.2 to 82.4 & \\
\hline Northern Thailand & 13 & 13 & $76.4 \pm 0.5$ & Current study and Kingsada et al. (2011) \\
\hline Zone B & & & 75.8 to 77.7 & \\
\hline Cambodia & & & - & Kingsada et al. (2011) \\
\hline Zone B & & & 76.1 to 79.9 & \\
\hline Central Thai Peninsula & 31 & 31 & $70.9 \pm 0.7$ & Current study and Kingsada et al. (2011) \\
\hline Zone C & & & 69.5 to 72.6 & \\
\hline Peninsular Malaysia & 10 & 10 & $78.7 \pm 0.7$ & Current study \\
\hline Southern Peninsula Thailand & & & 77.3 to 79.3 & \\
\hline Zone D & & & & \\
\hline
\end{tabular}




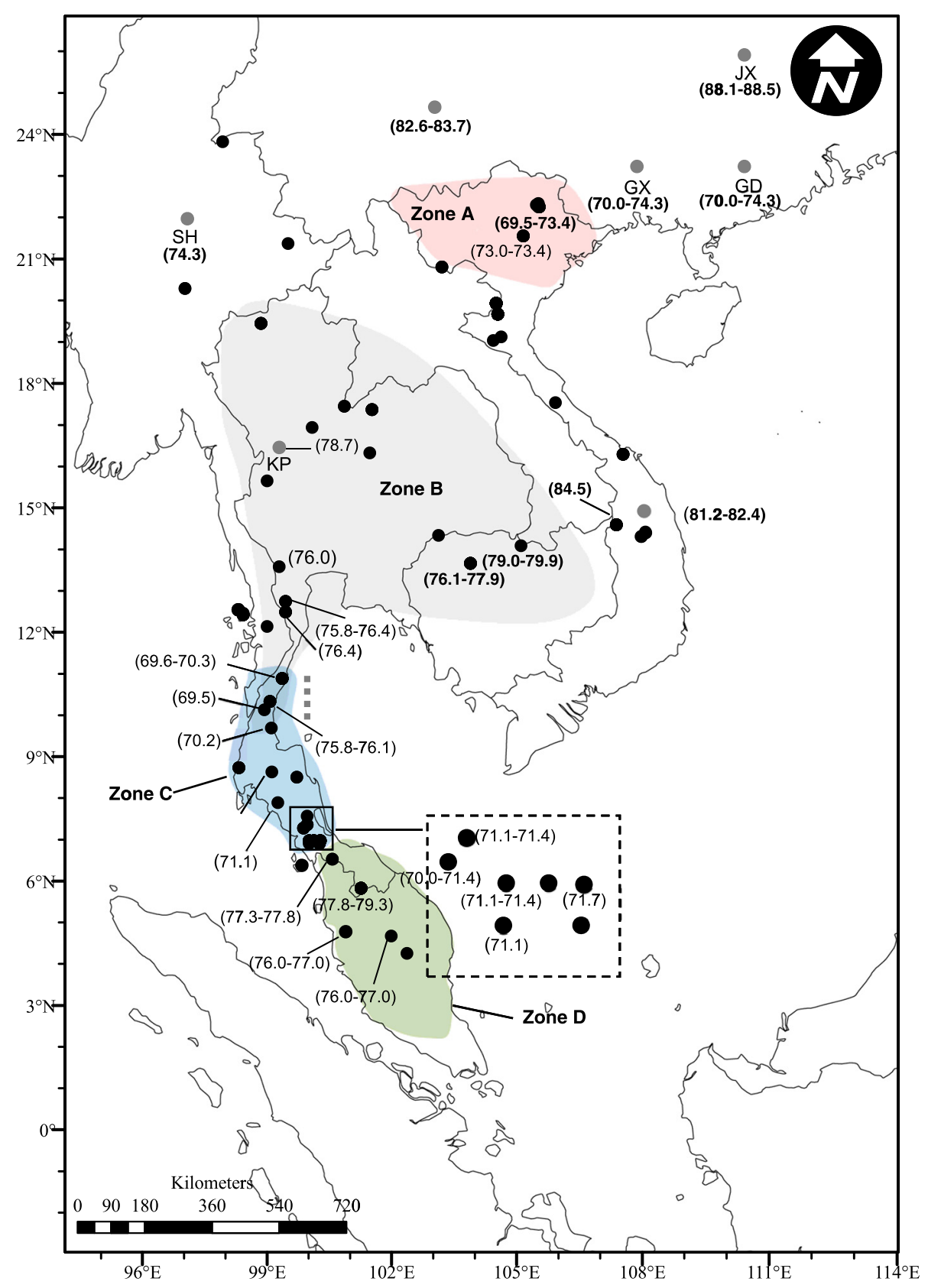

Figure 5 Patterns of echolocation call frequencies of Rhinolophus affinis within mainland Southeast Asia. Black circles correspond to the collection locality map in Figure 1 whereas gray circles are approximate localities from literature, KP = Kamphaeng Phet, JX = Jiangxi, GD = Guangdong, GX = Guangxi, QN = Quang Nam, SH = Shan, and YN = Yunnan. Color shades are FMAXE zones and a vertical dashed-line demarks a locality where zones B and C frequencies were found overlapped. Values in parentheses are peak frequency (FMAXE) in kHz which are bold figures based on literature.

(Figures 8 and 9). The uncorrected pairwise sequence distances ( $p$-distance) between the Indochinese subregion and the Sundaic subregion were 9.1\% (D-loop) and $2.4 \%(\mathrm{COI})$.

In analyzing D-loop data, two subclades were recovered within each main clade: Subclade ia, ib, iia, and iib nested within clades i and ii, respectively. Subclade ia and ib were both from the peninsular Thailand area of the Sundaic region (Figure 9) yet showed rather high genetic distance (8.3\%) with a bootstrap support of $97 \%$. The genetic distance between iia and iib was lower (5.0\%). Sequences of clade iia were from southern 


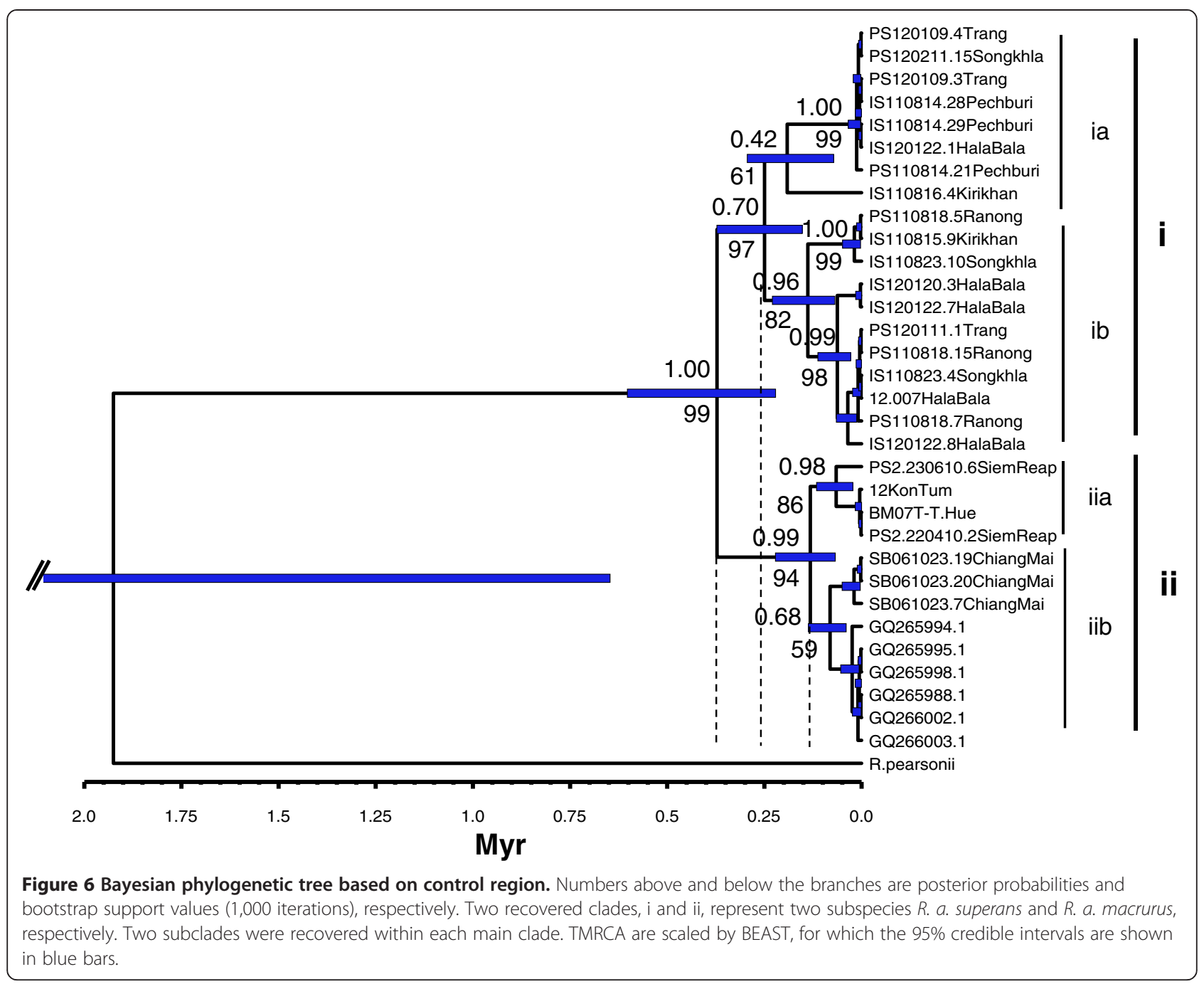

Vietnam (Kontum and Thua Thien-Hue provinces) and north-western Cambodia (Siem Reap province), while clade iib comprised sequences from Chiang Mai province and southern China. The split between iia and iib was supported by a bootstrap value of $94 \%$.

In analysis of COI, two subclades were recovered within clade III (subclades IIIc and IIId) with a genetic distance of $1.7 \%$ between them. Clade IIIc is comprised of sequences from the upper north-western Vietnam (Hoang Lien Son and Lao Cai) and upper southern China (Hunan), and clade IIId is comprised of sequences from central Vietnam (Quang Nam) and southern Vietnam (Lam Dong) (Figure 8).

Base on COI gene, among the Indochinese clades (clades II and III combined), clade III shares a recent common ancestor with the Sundaic clade (clade I) rather than to its closest geographical clade (clade II) (Figure 7). This is also reflected by the genetic distance $1.7 \%$ (clade I vs. II) and $2.9 \%$ (clade II vs. III) (a table of average percentage of genetic distance was not include). Bayesian estimates of time to the most recent common ancestor (TMRCA) provided effective sample size values of $>500$ for all parameters. The inferred TMRCA for all recovered clades, including Sundaic and Indochinese clades (i vs. ii) was 391,000 years BP (95\% CI 222,000 to 603,000) (Figure 6), corresponding to a period of maximum glaciation of the Pleistocene glacial cycling (Shi et al. 2006). The TMRCA for ia vs. ib was 256,000 years BP (95\% CI 152,000 to $372,000)$, whereas the TMRCA for iia vs. iib was slightly more recent at 139,000 years BP $(95 \%$ CI 68,000 to 222,000).

\section{Variation within Indochinese subregion population}

In the Indochinese subregion, noteworthy morphometric variations were observed. A multivariate analysis based on selected 21 external and cranial characters classified the Indochinese specimens (referred to $R$. a. macrurus) into three forms (Figure 10). Northern Cambodia and 


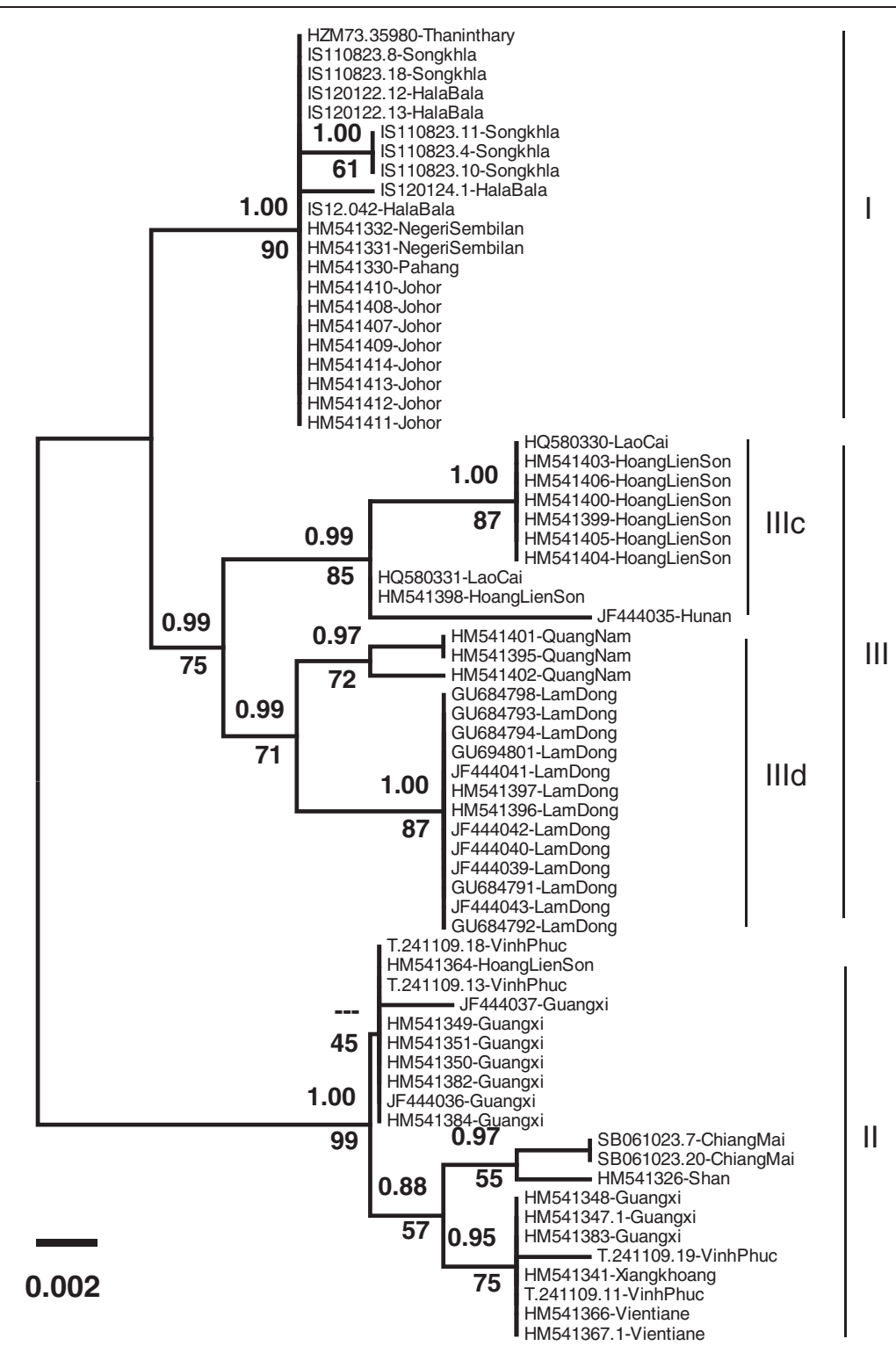

Figure 7 Maximum likelihood tree based on COI gene. Numbers above and below the branches are posterior probabilities and bootstrap support values (1,000 iterations), respectively. Three clades (I, II, and III) were recovered, the current sequences from the peninsular nested in clade I and sequences from northern Vietnam and northern Thailand nested in clade II therefore represent two subspecies $R$. $a$. superans and $R$. $a$. macrurus, respectively. None of the current sequence data nested in clade III. The later comprised all sequences from the GenBank and may represent a different taxon.

south-eastern Thailand (Surin Province) specimens (form A) were smaller in forearm, tail, foot, and wing measurements (Table 3). This variation was supported genetically with D-loop results (subclade iia). Sequences nested with those from central Vietnam (Kon Tum and Thua Thien-Hue) forming a sister clade to Chiang Mai and southern China sequences (iib). The second form (form B) was found from the lower northern Vietnam (Nghe An province) and east Myanmar and was characterized by a smaller nose leaf and smaller skull measurements (Table 3). Unfortunately, genetic data was not available for specimens of this form as only old tissue was available for analysis which did not sequence well. The third form (form C) was more widespread and found from central Myanmar, northern Thailand, northern and southern Vietnam. This form has comparable skull morphology to form $\mathrm{A}$, which in turn is generally larger than form B. Form $\mathrm{C}$ was supported by available COI sequences from Chiang Mai and Vinh Phuc, and forms its own clade (subclade IIId) as a sister clade to IIIc (sequences from Lao Cai and Hoang Lien Son, Vietnam and Hunan, China). 


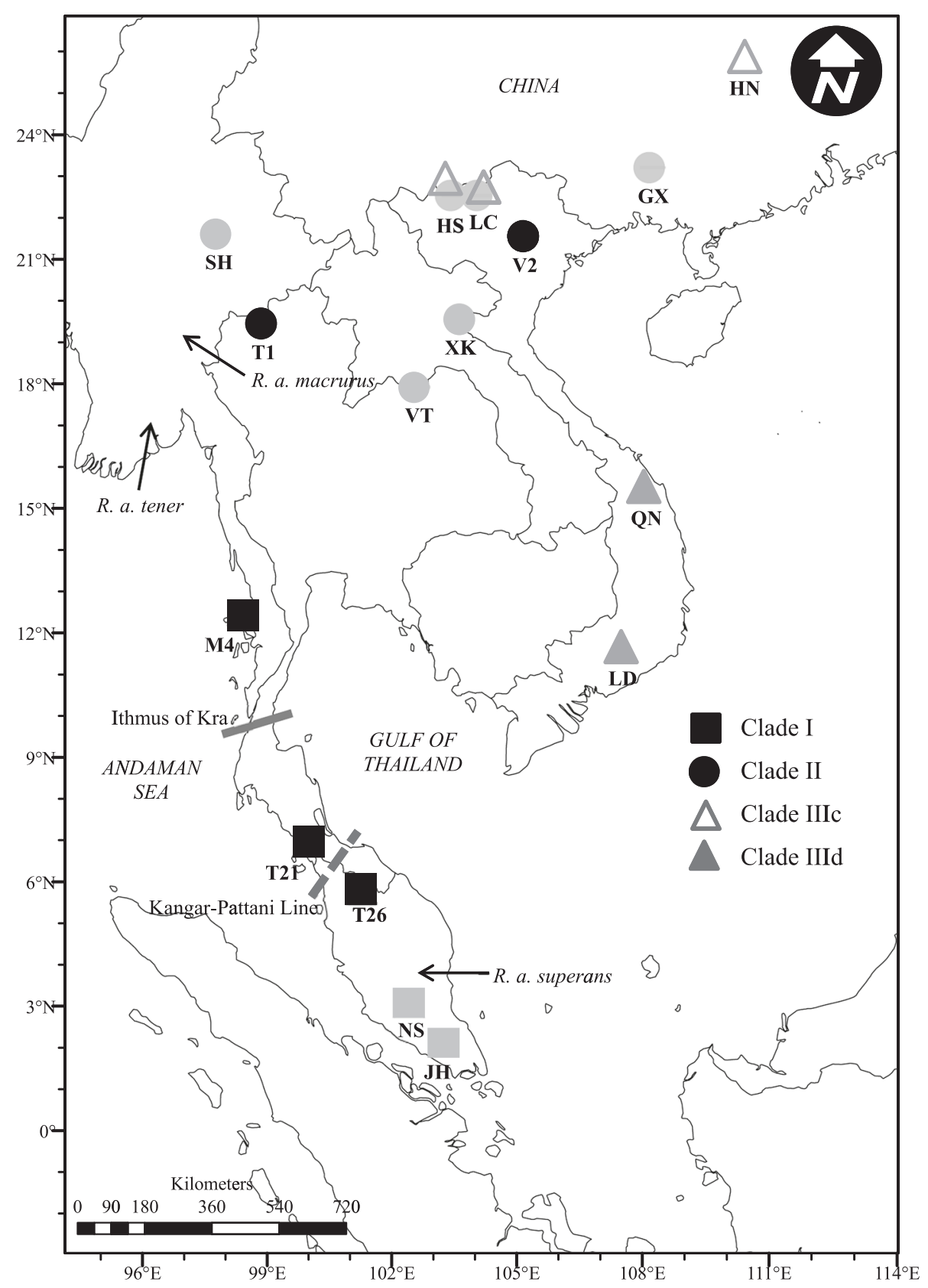

Figure 8 Cytochrome c oxidase subunit I (COI) distribution of Rhinolophus affinis from mainland Southeast Asia. The shapes of the symbols correspond to the defined clades in Figure 9 . Black symbols are sequences from particular localities of the current study whereas gray symbols are sequences from GenBank (HN = Hunan, HS = Hoang Lien Son, QN = Quang Nam, GX = Guangxi, LC = Lao Cai, LD = Lam Dong, $\mathrm{SH}=$ Shan, $\mathrm{VT}$ = Vientiane, $\mathrm{XK}=$ Xiangkhouang). Gray solid line (Ithmus of Kra) and dashed lines (Kangar-Pattani Line) are the biota transition zones proposed in the peninsular. The arrows indicate the approximate localities of subspecific forms in the research area.

Based on nose leaf characteristics, form B has a notably small nose leaf (Figure 11C) compared to $R$. a. macrurus (Figure 11B) and R. a. superans (Figure 11A) with a less rounded horseshoe (rather elongated posteriorly) with the anterior median emargination of the horseshoe being rather deep and narrow. The sella is narrow and moderately high (Figure 11G). The base of the sella is always enlarged, being about $30 \%$ reduced in size compared to the typical forms of $\mathrm{A}$ and $\mathrm{C}$. The lateral margin varies from slightly concave in the middle to almost parallel sided, with the tip varying from rounded to almost squared-off in some individuals. The internarial cup is small, the lateral margin of the cup being well defined and raised which results in a deeper median internarial cup. The connecting process is 


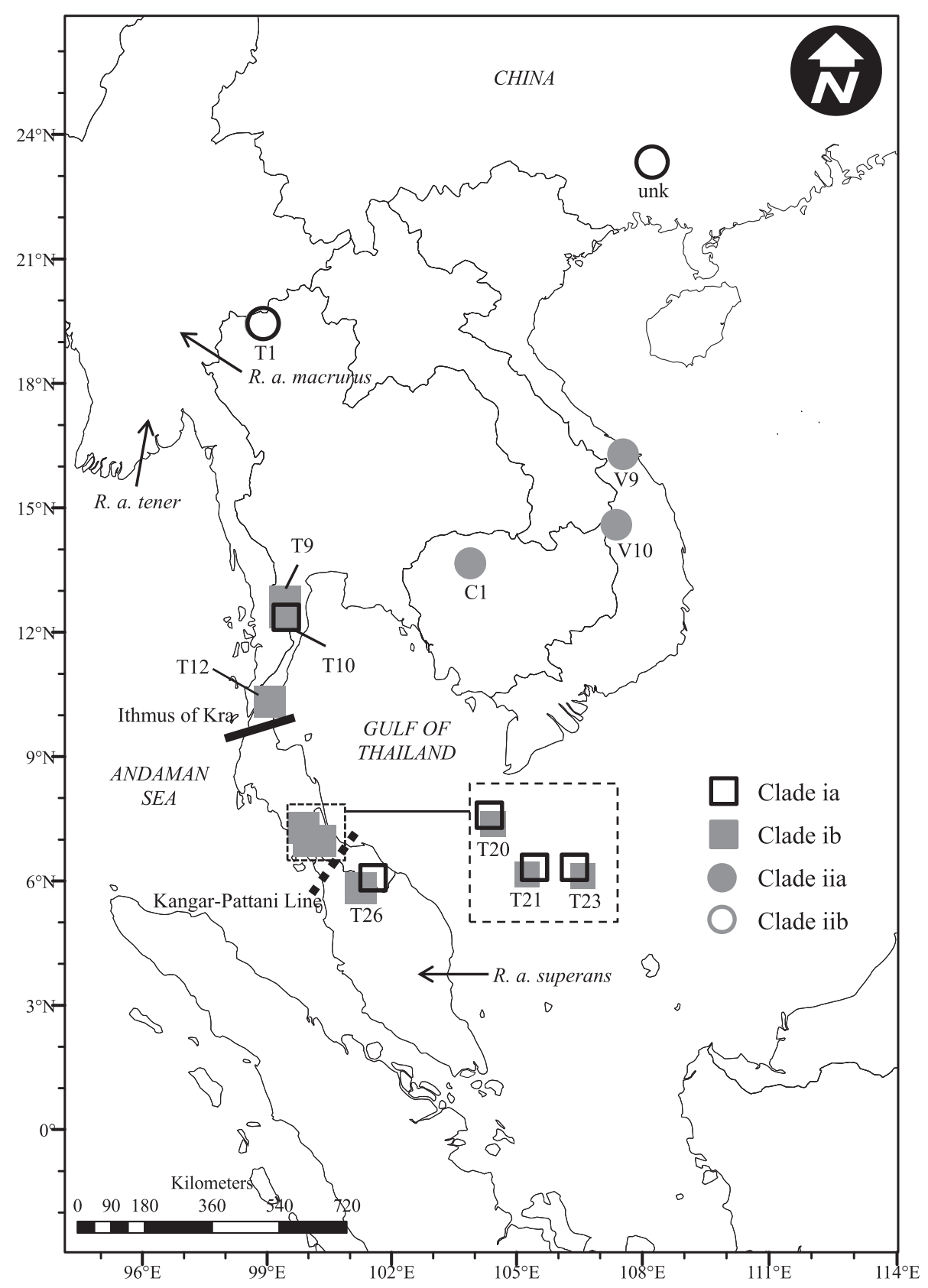

Figure 9 Control region gene (D-loop) distribution of Rhinolophus affinis from mainland Southeast Asia. The shape of the symbols corresponds to the clades defined in Figure 6. Unk = unknown locality in China where sequences were accessed from GenBank. Black solid line (Ithmus of Kra) and dashed lines (Kangar-Pattani Line) are the biota transition zones proposed in the peninsular. The arrows indicate the approximate localities of subspecific forms in the research area.

smaller (Figure 11D), as being slender and less rounded. The lancet is slender and narrower with an elongated tip. The basal part is not obviously larger than the middle and tip, respectively, resulting in a less triangular shaped lateral margin. Forms $\mathrm{A}$ and $\mathrm{C}$ have comparable nose leaf morphology, specimens generally have a wider horseshoe (Figure 11B), with the anterior median emargination being deeper and with a well-defined notch. The sella is broader and higher (Figure 11F); the connecting process is larger and more rounded (Figure 11E); the lancet is broader and more enlarged at the base and the internarial cup is also broader.

In skull morphology, form B has smaller skull measurements in general. This population has shorter lower and upper tooth row (Figure 12E-F) compare to forms A and $\mathrm{C}$ (Figure 12C,D) and the Sundaic form, $R$. $a$. 


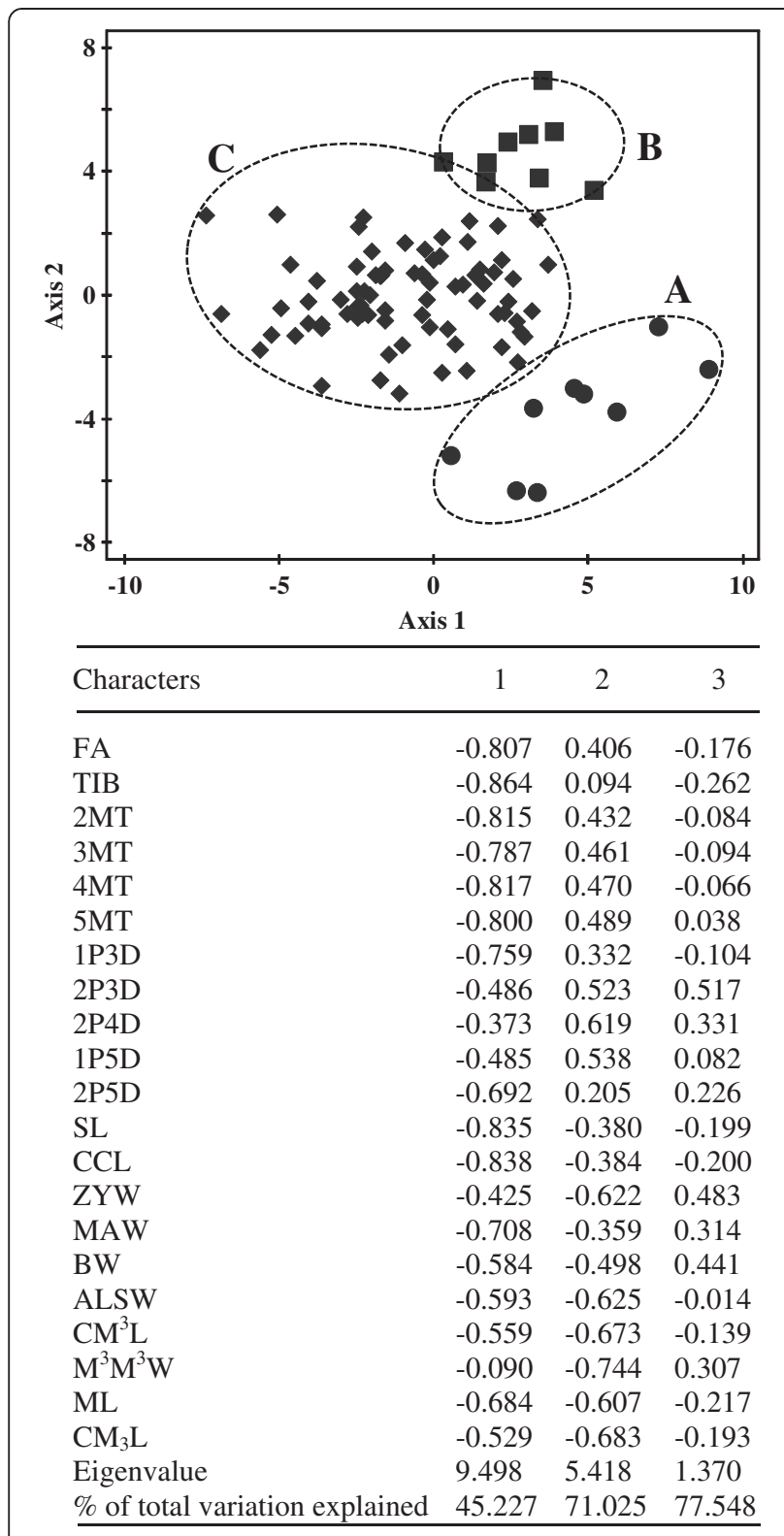

Figure 10 PCA based on 21 external and cranial characters of specimens from Indochinese subregion. A total of 94 specimens were classified into three groups based on 21 external and cranial characters. Specimens from Shan (Muse and Taung Pauk), northern Thailand, northern, central and southern Vietnam clustered as group C (diamond) represents $R$. a. macrurus; central Vietnam and an individual from east central Myanmar (Keng Tung) formed group B (square) which represents $R$. cf. affinis, while Cambodian specimens formed the third group A (circle) which represents a subform of R. a. macrurus. Different groups were circled with dashed circles.

superans (Figure 12A,B). Form B was found to have a smaller braincase and rostrum (Figure 13E,F), narrower inter-orbital width, shorter palatal bridge (Figure 12F), and shorter nasal depressions (Figure 13F). This population has more compressed rostral compartments (anterior lateral swellings, anterior median swellings, and posterior median swellings), whereas forms $\mathrm{A}, \mathrm{C}$, and Sundaic have broader palatal bridges (Figure 12D,B), larger nasal inflations (Figure 13D,B), and more bulbous compartments (Figure 13C,A). The central Vietnam population (form $\mathrm{C}$ ) is supported genetically by COI results (clade IIId).

\section{Discussion}

Our results indicate that there are at least three forms of $R$. affinis distributed within mainland Southeast Asia; $R$. a. superans (Sundaic subregion), R. a. macrurus (Indochinese subregion), comprising of submorphological forms A and C (Figure 10), and R. cf. affinis (northern Vietnam and east of central Myanmar) morphological form B (Figure 10). Since the Sundaic and Indochinese forms are clearly differentiated by stable external, craniodental, and baculum characters that are strongly supported by genetic data as well as being geographically isolated, we refer the Indochinese form here to $R$. $a$. macrurus and the Sundaic form to $R$. a. superans following Andersen (1905) and as also recognized by Lekagul and McNeely (1977), Csorba et al. (2003), and Kingsada et al. (2011). The Indochinese form B is an undescribed form, and additional echolocation and genetic data are required to establish its status.

Although a well-known zoogeographic boundary between the two subregions occurs at the Isthmus of Kra $\left(10^{\circ} 30^{\prime} \mathrm{N}\right)$, the Sundaic morphological characters appear to extend north of this to Ratchaburi province (Figure 14). Based on morphological and genetic data, it is clear that $R$. a. macrurus and $R$. a. superans meet north of the Kra Isthmus to Ratchaburi province, which is a similar pattern to that observed in snakes (Pauwels et al. 2002, 2003), other bats (Hughes et al. 2011; Woodruff and Turner 2009), and non-volant mammal species (Woodruff and Turner 2009). Form B is known from a small disjunct distributional area including lower northern Vietnam and eastern Myanmar.

As mentioned in the 'Background' section, we were not able to define the subspecific form of $R$. a. tener which was described from Pegu, south-west Myanmar (see Figure 1) due to lack of available material. This subspecies was described as being small in size (Andersen 1905), with small ears, less than $20 \mathrm{~mm}$ (Sinha 1973), a narrow horseshoe (Sinha 1973), a short tail and rather long tibia, a short skull, narrow nasal swellings and braincase, and a short tooth-row (Andersen 1905). Although $R$. a. tener is smaller in size compared to average measurements of $R$. a. macrurus, measurement ranges overlap (Table 3). Only the ear length, skull length, braincase and anterior lateral swellings of holotype specimens appeared to be smaller than the minimum values for $R$. a. macrurus. Accurately defining $R$. a. tener is 

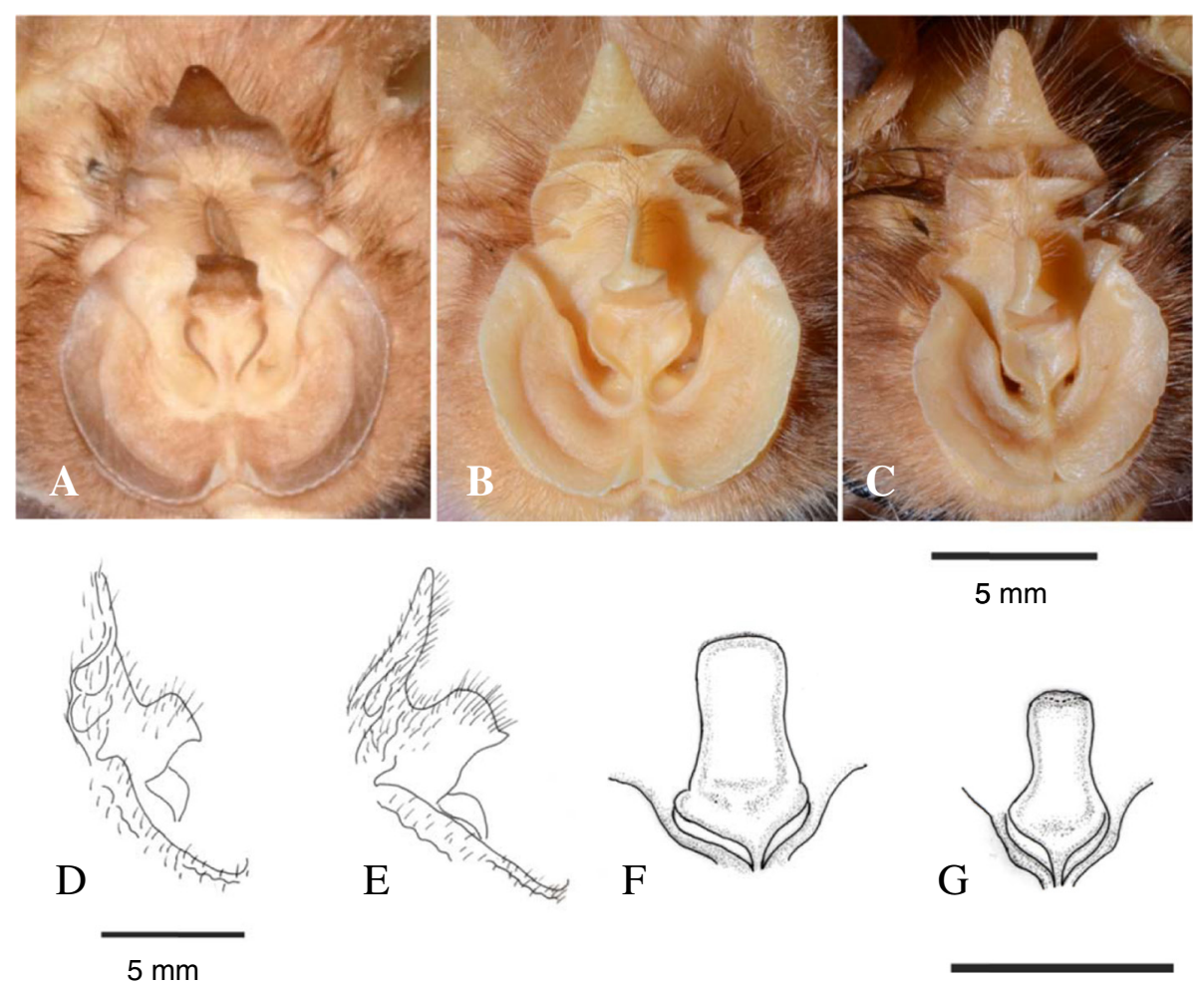

$5 \mathrm{~mm}$

$5 \mathrm{~mm}$

Figure 11 Nose leaf variation of Rhinolophus affinis. (A) R. a. superans (specimen from Songkhla, central peninsular Thailand); (B, E, F)

R. a. macrurus (specimen from Vinh Phuc and Nghe An, northern Vietnam); and (C, D, G) form B (specimen from Nghe An, northern Vietnam).

therefore difficult due to insufficient samples and high degree of morphological variation in $R$. affinis.

The morphological transition rule the more southern or south-eastern the habitat, the longer the ears, the broader the horseshoe, the longer the tibia, the larger the skull, the broader the nasal swellings, and the longer the toothrows' proposed by Andersen (1905) was incongruent with form $\mathrm{B}$ recorded from the lower northern Indochinese subregion. This form has an overlapping distribution with $R$. a. macrurus yet appears to be smaller in most nose leaf and craniodental characters. In addition, $R$. a. macrurus from central and southern Vietnam are smaller in ears, tibia, skull, and nasal swellings compared to more northerly populations within the Indochinese subregion (Table 3). Therefore, the morphological rule is unlikely to be generally accepted since $R$. affinis shows high intraspecific variation in morphology. In general, we found that the horseshoe and nasal swellings size are negatively correlated with the echolocation call frequencies. The rule is likely true when observing broader distribution ranges, e. g., comparisons between $R$. a. himalayanus, $R$. a. macrurus, $R$. a. superans, and $R$. a. princeps, but exceptions to the rule occur when more samples are examined from each region, such as the small form from Kangean Islands (Bergmans and van Bree 1986; Thomas 1997).

\section{Genetics}

Phylogenetic analysis of $\mathrm{COI}$ and control region gave comparable results, supporting the separation of the Sundaic and Indochinese forms, which are referred to $R$. a. superans and $R$. a. macrurus, respectively, following current taxonomy (Csorba et al. 2003; Kingsada et al. 2011; Koopman 1994). Genetic divergences observed were also supported by morphometric characteristics, namely cranial and bacular data.

The genetic separation observed generally agrees with existing biogeographical demarcations for the region (de Bruyn et al. 2005; Hughes et al. 2003, 2011; Khan et al. 2010; Woodruff and Turner 2009). The genetic split in $R$. affinis is very recent (c. 400,000 before present $[\mathrm{BP}]$ ) (Figure 6), just falling within the glacial period of the Pleistocene epoch when sea levels fluctuated to between 60 to $80 \mathrm{~m}$ below present sea level (Woodruff and Turner 2009). Sea levels dropped to $30 \mathrm{~m}$ below the present region's area doubled in size and provided extensive dry land habitat (Woodruff 2010). Malay peninsula was progressing a drier, grass-Pinus savannah 

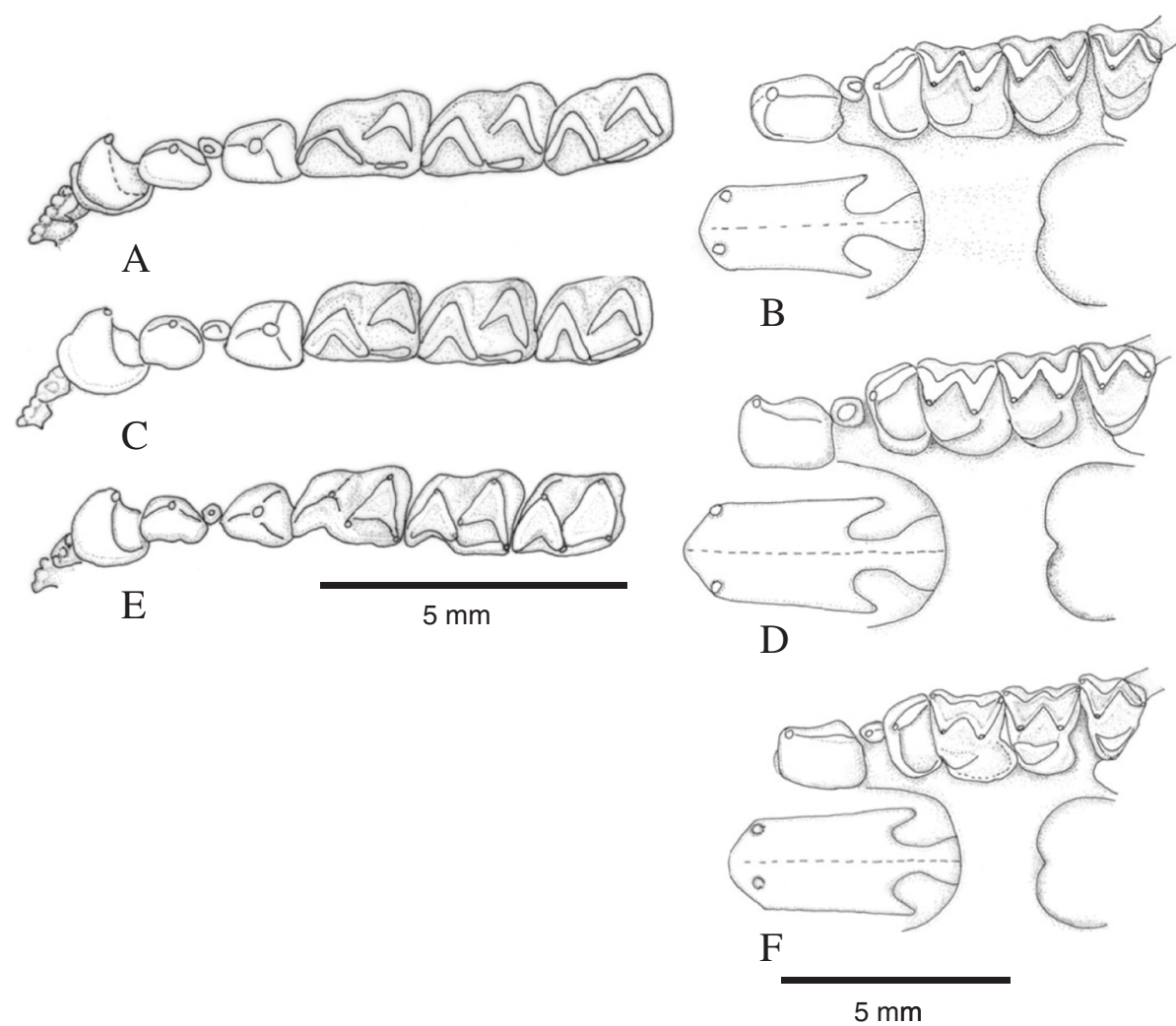

Figure 12 Dental and palatal bridge variation of Rhinolophus affinis. (A, B) R. a. superans (specimen from Surathani, central peninsular Thailand); (C, D) R. a. macrurus (specimen from Vinh Phuc, northern Vietnam); and (E, F) form B, (specimen from Nghe An, lower north Vietnam).

system (Heaney 1991; Morley 2000; Gathorne-Hardy et al. 2002). At this time, large areas of the peninsula emerged and connected many present-day islands. Therefore, the rapid fall in Pleistocene sea levels (Woodruff and Turner 2009; Woodruff 2010), climatic zones (Hughes et al. 2011), and phytogeographical transitions (Baker et al. 1998; Good 1964; Keng 1970; Richards 1996; van Steenis 1950; Whitmore 1984; Wikranmanayake et al. 2002) likely explain the genetic variation observed in $R$. affinis rather than the high sea level hypothesis when marine waters (100 m, 150 to $220 \mathrm{~m}$ above the present level) breached the peninsula during the Neogene period (Hughes et al. 2003; Hutchison 1989; Woodruff 2003). Therefore, Pleistocene climate may have played an important role in shaping the genetic profile of $R$. affinis (Mao et al. 2010) from the peninsula.

The two subclades (control region, ia and ib) (Figure 6) observed from the Sundaic region which represent $R$. $a$. superans are of interest as the genetic cline was not supported by morphometric data, bacular morphology, echolocation call frequencies, or biogeographical demarcations. The split of the subclades (ia vs. ib) was more recent (c. 200,000 years BP) and also falls within the glacial period of Pleistocene. However, seven sequences (IS110823.4, IS120216.8, IS110823.10, IS120214.16,
IS120215.10, IS120214.17, and IS12.042 - change codes) which were available for COI analysis did not show the separation pattern (clade I). Further population research is therefore recommended to clarify this cryptic genetic variation, and fast-mutating genes such as D-loop and microsatellites would be appropriate for such studies (Chen et al. 2006; Mao et al. 2010).

The genetic variation within the Indochinese subregion is also of note, with clades II and III of COI (Figure 7) suggesting there may be two lineages present. The clades of both lineages showed large genetic distances despite their geographical overlap. The separation was partially supported by morphology, with specimens from clade III (southern Vietnam) relatively smaller in many characters (Figure 15, Table 3). Echolocation calls from southern Vietnam were also higher in frequency (O' Shea and Gore, personal communication; Thong 2011). This lineage is distributed in the eastern part of Indochinese subregion extending from the upper southern China (a sequence from Hunan, China) down to central and southern Vietnam and Cambodia [(recovered clade iia of control region (Figure 6)]. It may have connected with the Sundaic lineage during the glacial period of the Pleistocene, resulting in closer genetic relationships with the Thai-Malaysia Peninsula clade (I vs. III) rather than the Indochinese 


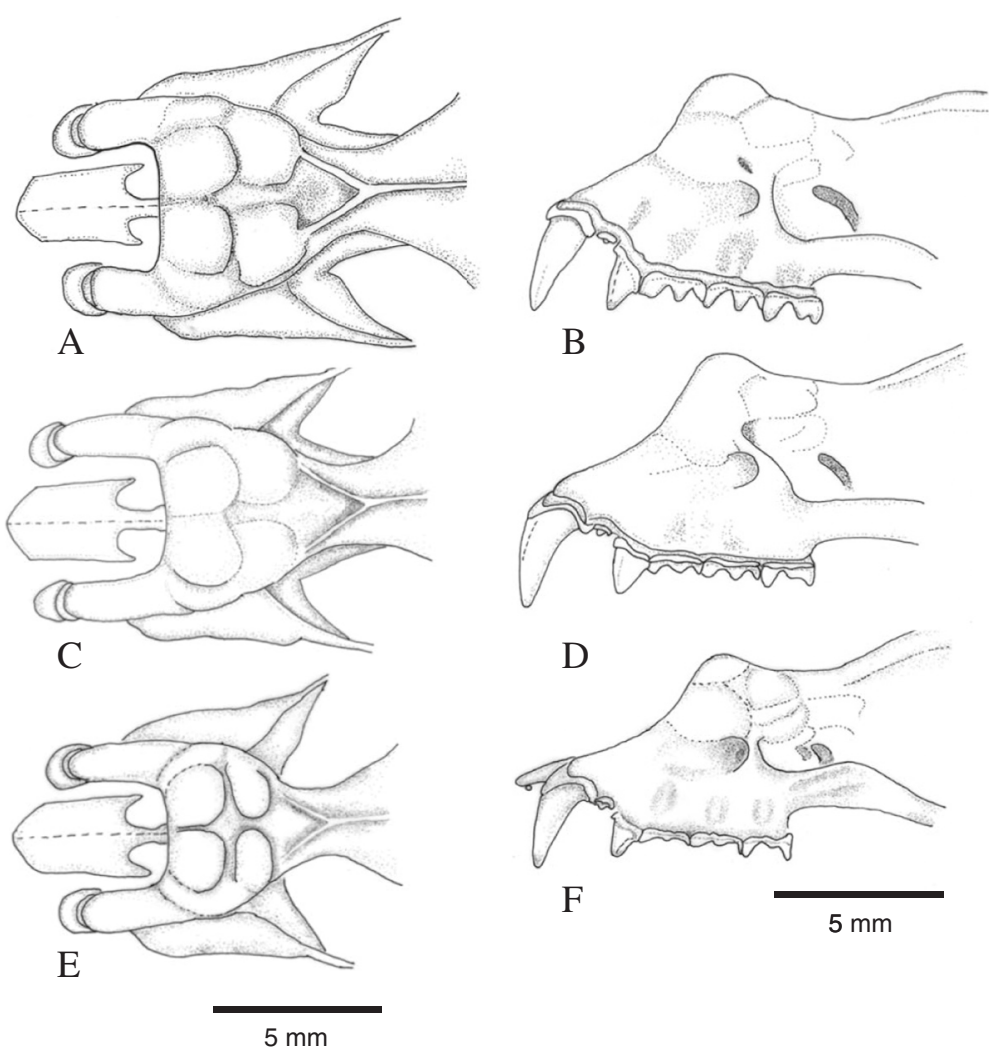

Figure 13 Rostrum variation of Rhinolophus affinis. (A, B) R. a. superans (specimen from Surathani, central peninsular Thailand); (C, D) R. a. macrurus (specimen from Vinh Phuc, northern Vietnam); and (E, F) form B, (specimen from Nghe An, lower north Vietnam).

clade II (Figure 7). This linkage may be attributable to the Pleistocene climate during glacial periods, when the sea level dropped around $100 \mathrm{~m}$ below present levels, exposing vast areas of shallow seabeds on the Sunda shelf (Voris 2000; Woodruff 2003; Hall 2013) which formed migration ways between the two subregions (Tougard 2001). For instance, the peninsula-restricted rhinolophid, $R$. stheno, was recorded as having an isolated population in central Vietnam (Bach Ma National Park) yet shares similar morphological characters with the peninsula population (Soisook et al. 2008). A similar pattern was also observed within the giant fresh water prawn Macrobrachium rosenbergii (de Bruyn et al. 2005). Lineage clade II (Figure 8) occurs from central to westward areas within the Indochinese subregion, extending from the coast of southern China (Guangxi) to the northern Vietnam (Vinh Phuc and Hoang Lien Son), northern Lao PDR (Vientiane and Xiangkhong), central Myanmar (Shan), and northern Thailand (Chiang Mai). This clade overlaps in distribution with subclade IIIc (Figure 7) yet showed the highest genetic distance (3\%) among the recovered clades, strong evidence which supports the hypothesis that two distinct taxa are present.

\section{Echolocation and morphology}

The variation in echolocation call frequency of $R$. affinis throughout the region resulted in the taxonomic status of this widespread species being re-examined (Kingsada et al. 2011). Call frequency has been found to be a useful tool for classification in bats, particularly among cryptic species (Thabah et al. 2006). Echolocation call frequencies of R. affinis in mainland Southeast Asia were comprehensively documented by Kingsada et al. (2011), but do not appear to be congruent with morphology or genetics.

The analysis of call frequencies showed a cline between both subregions to the lower southern area of the Peninsula, just around the Isthmus of Kra. High call frequencies $(\geq 75 \mathrm{kHz})$ were found to have a southern limit at Ranong province while lower call frequencies $(\leq 71 \mathrm{kHz})$ were found to have their northern limit at Chumphon province. In Ranong, both high and low frequencies were recorded. However, the high frequencies recorded from north of the Isthmus of Kra (Ranong, Prachuap Kiri Khan and Phetchaburi) were not supported by morphology and genetic data as belonging to the Indochinese subregion but grouped with material from the Sundaic subregion. 


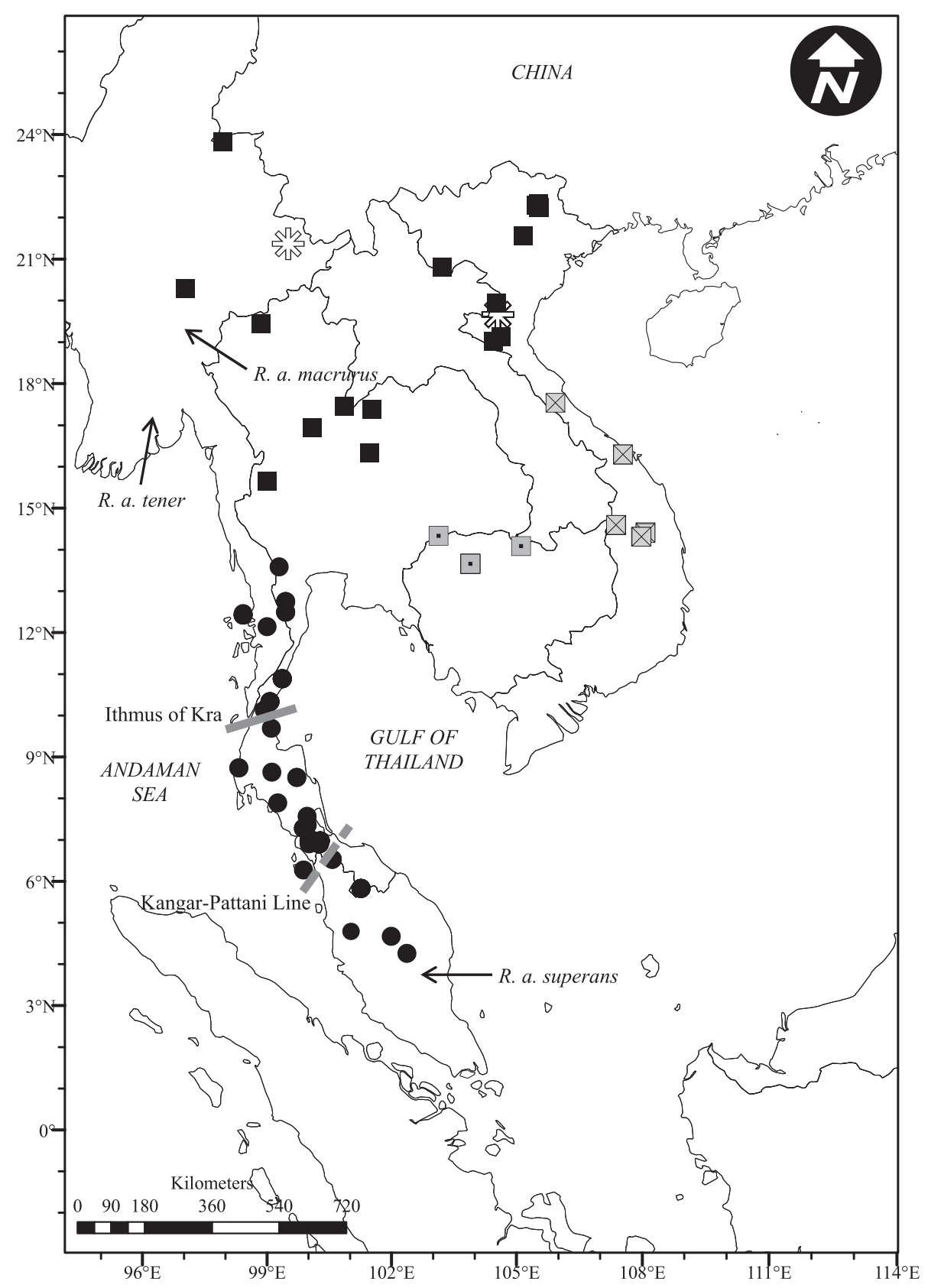

Figure 14 Morphological distribution of Rhinolophus affinis from mainland Southeast Asia. Circle represents morphological form from Thai-Malay Peninsula; solid square and crossed square represent morphological variation of form $C$; dot square represents morphological form A whereas asterisk represents the un-described form B ( $R$. cf. affinis). The defined forms (A, B, C) are corresponded to Figure 10. Gray solid line (Ithmus of Kra) and dashed lines (Kangar-Pattani Line) are the biota transition zones proposed in the peninsular. The arrows indicate the approximate localities of subspecific forms in the research area.

This highlights the general need for examination of morphological and genetic data in tandem with echolocation call data.

Here, we conclude that both the Sundaic and Indochinese forms are recognized and supported by morphological and genetic data, but share similar call frequencies in provinces to the north of the Isthmus of Kra. The Sundaic form of $R$. a. superans occurs from Ratchaburi province to the south; while the Indochinese form of $R$. a. macrurus occurs from Tak, Chaiyaphum and Surin to the north. Variation observed in call frequency within the Indochinese subregion was partially supported by morphological and genetic data. Though the high call frequency $(>80 \mathrm{kHz})$ from central Vietnam was supported, lower call frequencies 


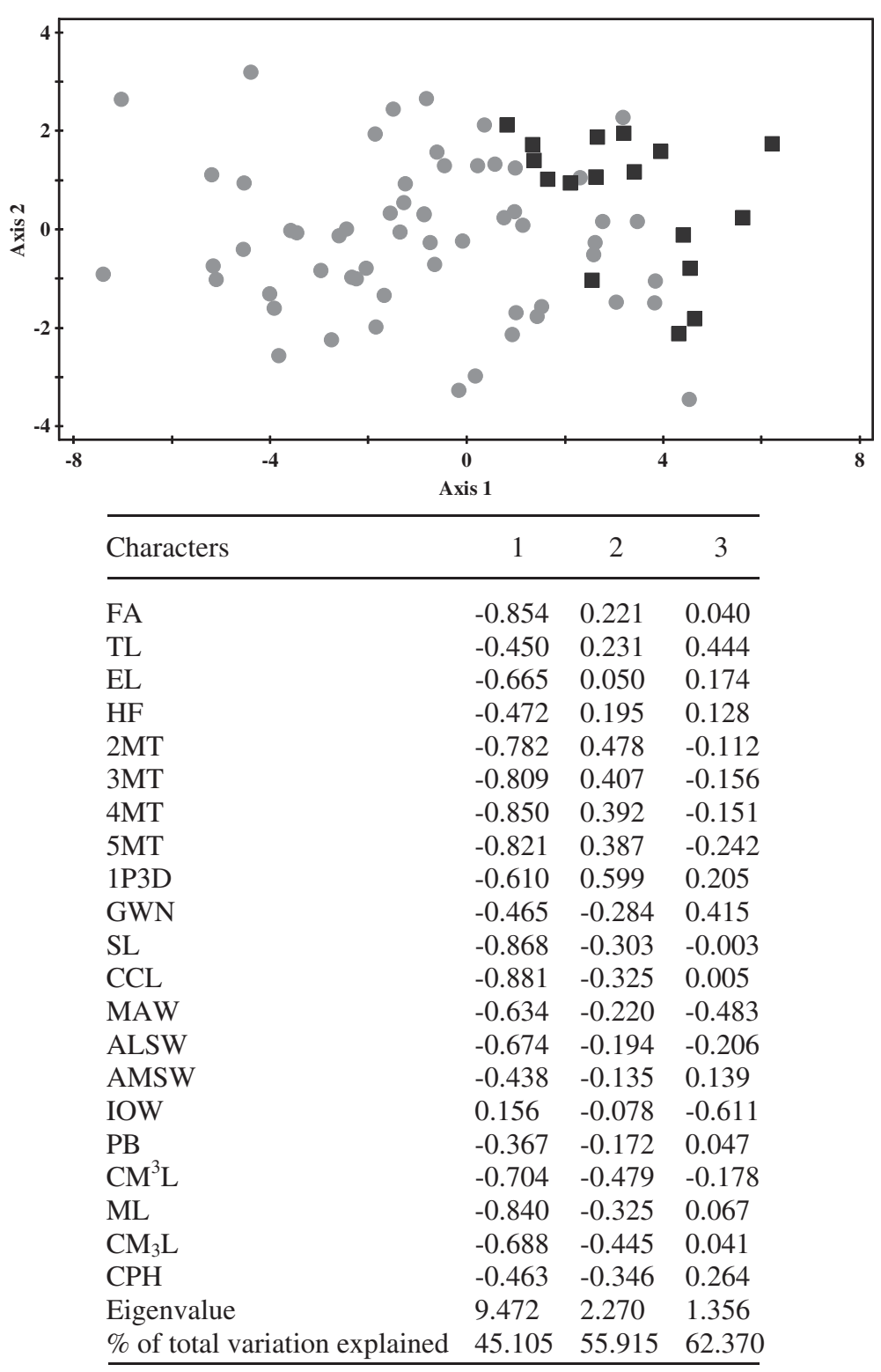

Figure 15 Morphological variation of $\boldsymbol{R}$. affinis from southern Vietnam. Based on 21 characters, 17 specimens from southern Vietnam (square) show the patterns of being relatively isolated from 53 specimens of form C (diamond) in Figure 10.

recorded from northern Vietnam and southern China were not. This was also the case with variations in call frequency observed in peninsular Thailand.

A significant negative relationship was observed between call frequencies and size of the rostrum and horseshoe within $R$. affinis, which is supported by previous research (Barclay and Brigham 1991; Barclay et al. 1999; Francis and Habersetzer 1998; Guillén et al. 2000; Heller and von Helversen 1989; Jacobs et al. 2007; Jones et al. 1993; Kingston and Rossister 2004; Robinson 1996; Soisook et al. 2008). This suggests adaption of populations to local environments, and during the evolutionary history of this species, shifts in echolocation frequency may have occurred prior to changes in their body size.

The degree of morphological variation in $R$. affinis is highlighted by the morphology of the as yet undesignated form B from Nghe An province, northern Vietnam, and eastern Shan, Myanmar. No call frequencies or genetic data were available; however morphologically, this population had the smallest cranial and nose leaf morphology of all the material examined. Based on our findings relating to relationships between size and call frequency, this population possibly emits a call frequency higher than 80 $\mathrm{kHz}$. By comparison, this form agrees closely with 
individuals from Mussoorie, northern India, albeit smaller overall. This suggests that $R$. a. himalayanus (or its immediate descendants) may have spread southward to northern Vietnam. In Vietnam, specimens were captured in Nghe An province where $R$. a. macrurus (form C) was also found. In Myanmar, the specimen was from Shan where many $R$. a. macrurus were also captured. Based on sympatric speciation, two morphologically different populations with sympatric distributions are considered to represent distinct species. Based on current knowledge, we suspect the clade IIIc (Figure 7) represents form B. This is likely, because (1) this population has cranial and nose leaf characteristics which produce the highest call frequency, (2) in the north, the highest call frequency populations are found in upper south China, and (3) clade IIIc comprises only sequences from the northern Vietnam and upper southern China where $R$. a. himalayanus was recorded. It would be of interest to assess call frequency and morphological data of specimens from Hoang Lien Son (extreme northern Vietnam) to compare with form B.

\section{Conclusions}

In conclusion, echolocation call data for $R$. affinis is not a robust taxonomic tool when considered in isolation as there is a significant degree of variation which is not explained or supported by genetic and morphological findings. $R$. affinis shows strong divergence between the zoological subregions, which is supported by morphology and molecular sequence data. The transition zone of the Sundaic form extends up to the northernmost peninsula area at least to Ratchaburi province which is known to be the transition zone for many other bat (Hughes et al. 2011; Woodruff and Turner 2009) and non-volant mammal species (Woodruff and Turner 2009). The Sundaic form represents $R$. a. superans and the Indochinese form represents $R$. a. macrurus. Rhinolophus cf. affinis (form B) from northern Vietnam and east of central Myanmar is of interest and may represent a distinct taxon, although more data, including echolocation call frequency and genetic sequence data are needed. This study has highlighted significant levels of variation in $R$. affinis throughout its distribution in mainland Southeast Asia. As the species has an extensive distribution throughout the continental and insular regions of Southeast Asia, it is likely that extensive taxonomic revision is required for the species throughout its range.

\section{Appendix 1}

Specimen numbers localities and geographical coordinates.

Cambodia: Phnom Kulen National Park [C1] (14 ${ }^{\circ}$ $21^{\prime} \mathrm{N}, 107^{\circ} 22^{\prime} \mathrm{E}$ ): museum numbers $\mathrm{CBC} 00587$ 웅,

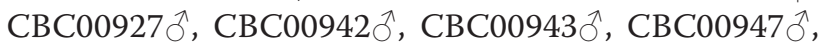

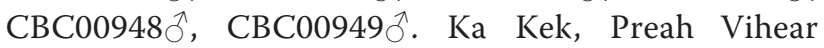

Protected Forest [C2] $\left(14^{\circ} 04^{\prime} \mathrm{N}, 105^{\circ} 17^{\prime} \mathrm{E}\right)$ : museum

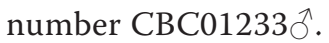

Malaysia: Kedah State: Langkawi Island [Ma1] (approximately $\left.6^{\circ} 23.204^{\prime} \mathrm{N}, 99^{\circ} 47.831^{\prime} \mathrm{E}\right)$ : museum number TK152867 ${ }^{\lambda}$. Penang State [Ma2] $\left(05^{\circ} 15^{\prime} 795\right.$ N, $100^{\circ} 29^{\prime}$ 076 E): museum number HZM 1.19418ㅇ. Kelantan State [Ma3] (approximately $5^{\circ} 10.462^{\prime} \mathrm{N}, 101^{\circ} 54.191^{\prime} \mathrm{E}$ ): museum number TK172726우. Pahang State [Ma4] (04 ${ }^{\circ} 16^{\prime}$ $281 \mathrm{~N}, 102^{\circ} 22^{\prime} 316 \mathrm{E}$ ): museum numbers TK153562 ${ }^{\lambda}$, TK153509웅.

Myanmar: Shan State: Muse Township [M1] (23 54' $\left.962 \mathrm{~N}, 97^{\circ} 49^{\prime} 000 \mathrm{E}\right)$ : museum number HZM

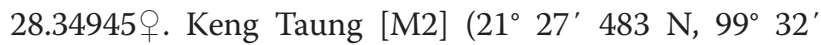
000 E): museum number HZM $3.36075{ }^{\lambda}$. Inle Lake [M3] (20 21' $\left.175 \mathrm{~N}, 96^{\circ} 53^{\prime} 189 \mathrm{E}\right)$ : museum numbers HZM 30.35224 ${ }^{\circ}$, HZM 29.35223 ${ }^{\circ}$. Taninthary Division: Katalu Village, Kadan ID [M4] (12 $22^{\circ} 436$ N, $98^{\circ} 24^{\prime}$ 191 E): museum numbers HZM 74.35981우, HZM 71.35978 ${ }^{\wedge}$, HZM 73.35980, HZM 72.35979․ Kyi Village, Kadan [M5] (12 30' 113 N, 98 $28^{\circ} 333$ E): museum number HZM 70.35977․ Hnedchey Khan Cave, Kyauk Taun Village [M6] (12 $11^{\prime} 400$ N, 99 00' 600 E): museum number HZM 31.35976 ․

Thailand: Chiang Dao Wildlife Sanctuary [T1] (approximately $19^{\circ} 30.556^{\prime} \mathrm{N}, 98^{\circ} 49.956^{\prime} \mathrm{E}$ ): field numbers PS110628.1 ${ }^{\lambda}$, SB061023.7웅, SB061023.20 ${ }^{\lambda}$, SB061023.19우, PP050807.1 $\hat{O}$. Petchaboon Province: Thung Sa Lang Luang National Park [T2] (16.34' 17' N, 100.52' 35' E): field number SB060518.12 ${ }^{\top}$. Loei Province: Phu Suan Sai

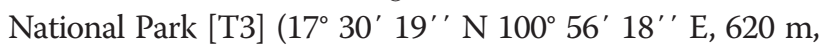
$975 \mathrm{~m}$ a.s.l): field numbers SB060516.9 ${ }^{\circ}$, SB060520.3 ${ }^{\lambda}$; Phuluang Wildlife Sanctuary [T4] (17 $25^{\prime} 742$ N, $101^{\circ} 38^{\prime}$

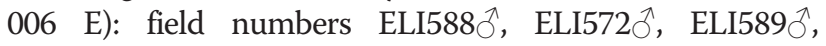
ELI563우. Chaiyapum Province: Hukieo Wildlife Sanctuary [T5] (16 $\left.18^{\prime} \mathrm{N}, 101^{\circ} 52^{\prime} \mathrm{E}\right)$ : field number SB060408.1우. Tak Province: East Thung Yai Naresuan Wildlife Sanctuary [T6] (15 42' 26' $\mathrm{N}, 98^{\circ} 59^{\prime} 28^{\prime \prime}$ E): field number SB030311.7 ${ }^{\prime}$. Surin Province: Huai Thap Than-Huay Sumran Wildlife Sanctuary [T7] $\left(14^{\circ} 21^{\prime} 08^{\prime \prime}\right.$ N, 103 $15^{\prime}$ 54' E): field number SB000128.7 ${ }^{\prime}$. Ratchaburi Province: Mae Nam Pha Chi Wildlife Sanctuary [T8] (13 ${ }^{\circ} 18^{\prime} 142$ N, 99 25'009 E): field number PS080120.3 ${ }^{\prime}$. Petchaburi Province: Kaeng Kra Chan National Park [T9] (approximately $12^{\circ} 47^{\prime} 965 \mathrm{~N}, 99^{\circ} 27^{\prime} 812 \mathrm{E}$ ): field numbers

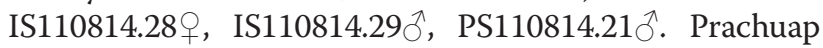
Kiri Khan Province: Kaeng Kra Chan National Park [T10] (approximately $12^{\circ} 32^{\prime} 228 \mathrm{~N}, 99^{\circ} 27^{\prime} 812 \mathrm{E}$ ): field numbers IS110815.3우, IS110815.9우, IS110816.4 ${ }^{\uparrow}$. Ranong Province: Krom Luang Chumpon Wildlife Sanctuary [T11] (10 22' $21 \mathrm{~N}, 99^{\circ} 04^{\prime} 27 \mathrm{E}$ ): field numbers PS110818.15 ${ }^{\lambda}$, PS110818.16 ${ }^{\prime}, \mathrm{PS} 110818.5 \hat{\circ}$, PS110818.9우. Chumphon Province: Khao Kram cave [T12] (10 $55^{\prime} 08^{\prime \prime}$ N, 99 $22^{\prime}$ $26^{\prime \prime}$ E, $67 \mathrm{~m}$ a.s.l): field numbers SB061010.16 ${ }^{\lambda}$, SB061010.39 $\hat{\partial}, \quad$ SB061010.23 $\hat{\partial}, \quad$ SB061010.33우, SB061 


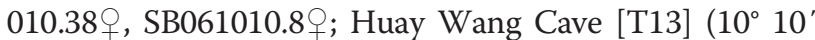
$00^{\prime \prime} \mathrm{N}, 98^{\circ} 55^{\prime} 11^{\prime \prime} \mathrm{E}, 55 \mathrm{~m}$, a.s.l): field number SB070110.4 ${ }^{\prime}$; Klao Plu Cave [14] $\left(09^{\circ} 43^{\prime} 36^{\prime \prime} \mathrm{N}\right.$, $99^{\circ} 06^{\prime}$ $30^{\prime \prime}$ E): field number SB070109.4 ${ }^{\circ}$. Pang Nga Province: North Surin Island [T15] (approximately 8 46' $200 \mathrm{~N}, 98^{\circ}$ 18' 600 E): field numbers SB060202.7 $\hat{\text {, SB060202.8 }}$. Surat Thani Province: Rajjaprabha Dam and Khlong Saeng Wildlife Sanctuary [T16] (approximately 8 58' 885 N, 97 47' 706 E): field numbers PS110831.1 ${ }^{\lambda}$, SB120117.1 ${ }^{\lambda}$. Nakhon Si Thammarat Province: Khao Phlu Cave [T17] ( $8^{\circ} 32^{\prime} 250$ N, 99 $43^{\prime} 396$ E): field numbers SB111015.6수, SB111015.9ㅇ. Krabi Province: Khao Pra Bang Kram Wildlife Sanctuary [T18] $\left(7^{\circ} 55^{\prime} 31 \mathrm{~N}, 99^{\circ} 15^{\prime} 47 \mathrm{E}\right)$ : field no. PS120504.9 ${ }^{\lambda}$. Pattalung Province: Khao Ban Tad Wildlife Sanctuary [T19] (approximately $7^{\circ} 23^{\prime} 48$ N, 99 $58^{\prime} 40 \mathrm{E}$ ):

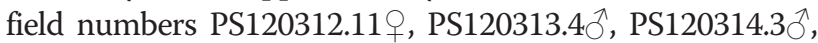
PS120314.5․ Trang Province: Khao Ban Tad Wildlife

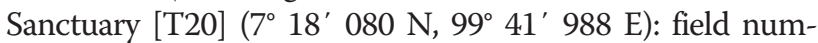
bers PS120109.3우, PS120111.1어, PS120109.4ㅅ․ Songkhla Province: Khuan Khao Wang Forest Park, Rattaphum District [T21] $\left(7^{\circ} 00^{\prime} 776 \mathrm{~N}, 100^{\circ} 01^{\prime} 259 \mathrm{E}\right)$ : field numbers PS120211.15 ${ }^{\lambda}$, IS110823.18우, IS110823.10 ${ }^{\lambda}$, IS110823.4우, IS110823.8 ${ }^{\lambda}$, IS110823.11 ${ }^{\lambda}$; Ton Nga Chang Wildlife Sanctuary [T22 to 25] (approximately 6 ${ }^{\circ} 55^{\prime}$ $783 \mathrm{~N}, 100^{\circ} 16^{\prime} 299 \mathrm{E}$ ): field numbers PS120211.15 ${ }^{\wedge}$, SB061216.18 ${ }^{\lambda}, \mathrm{SB} 070401.1 \hat{\jmath}, \mathrm{SB} 070401.3 \hat{\partial}, \mathrm{SB} 08050$ 4.26스, SB62001.14우, SB061001.10ㅅ, SB061001.13우,

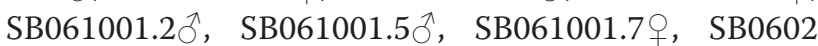

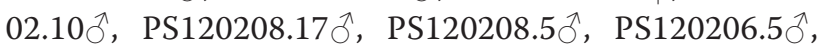
PS120204.3 $\hat{\jmath}$, PS120206.12 $\hat{\jmath}, \mathrm{SB} 061007.3 \hat{\jmath}, \mathrm{SB} 0610$ 01.14 9 ; Khao Namkhang National Park [T26] (6 $6^{\circ} 33^{\prime}$

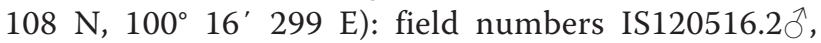
IS120516.1 $0^{\top}$. Narathiwat Province: Hala Bala Wildlife Sanctuary [T27] $\left(05^{\circ} 47^{\prime} 54^{\prime \prime} \mathrm{N}, 101^{\circ} 49^{\prime} 30^{\prime \prime}\right.$ E): field numbers IS120122.13 $\hat{\partial}$, IS120123.3 $\hat{\gamma}$, IS120124.1 $\hat{\partial}$,

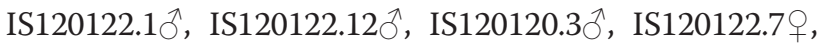
IS120122.8우.

Vietnam: Bac Kan Province: Kim Hy Nature Reserve

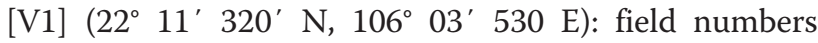
NF.030706.12 , NF.030706.9 9 , NF.030706.10 9 , NF.030

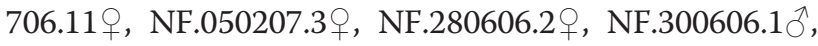
NF050207.4ㅇ. Vinh Phuc Province: Tam Dao National Park [V2] (21 $\left.30^{\circ} 448 \mathrm{~N}, 105^{\circ} 36^{\prime} 4,924 \mathrm{E}\right)$ ): field num-

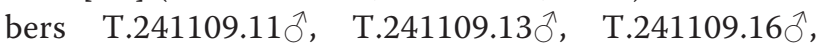
T.241109.18 $\overbrace{}^{\lambda}$, T.241109.19 ${ }^{\lambda}$. Son La Province: Tin To Area, Sop Cop Nature Reserve [V3] $\left(20^{\circ} 49^{\prime} 758 \mathrm{~N}\right.$, $103^{\circ} 29^{\prime} 519 \mathrm{E}$ ): field numbers $47 \hat{\jmath}, 57 \hat{\jmath}, 50 \partial^{\lambda}$. Nghe An Province: $\mathrm{Pu}$ Hoat Nature Reserve: Que Phong District [V4] (approximately 19 $54^{\prime} 221 \mathrm{~N}, 104^{\circ} 50^{\prime}$ 243 E): field numbers B027우, B-11 $\hat{0}, \mathrm{~B} 12$ (T89) $\hat{0}$, B47우, B94우, $\mathrm{T} 88 \hat{\jmath}, \mathrm{T} 91 / \mathrm{B}-02 \hat{\gamma}, \mathrm{B}-116$ 우, B-95우, B-

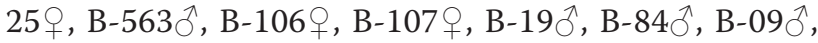

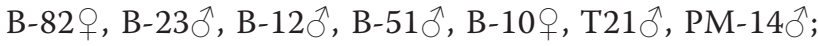
Ban Khom Cave [V5] (approximately 19 54' 221 N, $104^{\circ} 50^{\prime} 243 \mathrm{E}$ ): field numbers T20 $\partial^{\prime}$, No $78 \hat{\partial}$, No $98 \hat{\partial}$,

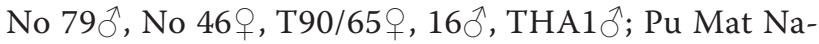
tional Park: Phu Nong Mount [V6] (19 01' 340 N, $104^{\circ} 44^{\prime} 726$ E): museum number HZM 20.32197웅 Khe Mat Ridge Cave [V7] (approximately 19 ${ }^{\circ} 01^{\prime} 340$

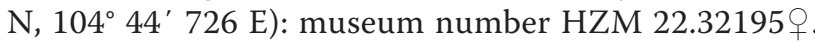
Quang Binh Province: Phong Nha National Park [V8] $\left(17^{\circ} 28^{\prime} 200 \mathrm{~N}, 105^{\circ} 31^{\prime} 200 \mathrm{E}\right)$ : museum number HZM 21.32196 ${ }^{7}$. Thua Thien Hue Province: Bach Ma National Park [V9] (16 10' 989 N, 107 52' 496 E): field numbers $\mathrm{BM} 06 \partial^{\lambda}, \mathrm{B}^{\circ} \hat{\partial}, \mathrm{BM} 07 \hat{\jmath}$. Kon Tum Province: Chu Mom Ray National Park [V10] (14 $29^{\circ} 021$ N, $107^{\circ}$ $\left.38^{\prime} 139 \mathrm{E}\right)$ : field numbers T13 (48)우, 64우, 12우, 23우, $45 ㅇ, 61 ㅇ$, 46우 47우, 65우. Gia Lai Province: Kon Cha Rang Nature Reserve [V11] (14 $17^{\circ} 400$ N, $108^{\circ} 21^{\prime} 600$

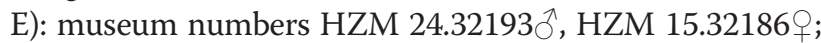
Kon Ka Kinh Nature Reserve [V12] (14 $11^{\circ} 400$ N, $108^{\circ}$ $15^{\prime} 000$ E): museum numbers HZM 12.32183 ${ }^{\lambda}$, HZM 16.32187 오.

\section{Competing interests}

The authors declare that they have no competing interests.

\section{Authors' contributions}

IS performed the data collection, identification of materials, statistical and genetic analysis, and drafting of the manuscript. CS, IS, NT, PB, and SB carried out the design of the study. NF, NT, and SB conceived the implementation of the study and helped to draft the manuscript. FAAK, NF, PB, PS, and VDT helped collecting the specimens. MW helped analyzing genetic data. All authors read and approved the final manuscript.

\section{Acknowledgements}

We are grateful to Nicholas J Souter, Sophany Phauk, Sarak Chheang, Gabor Csorba, Ibnu Maryanto, David Harrison, and Malcolm Pearch for providing us access to specimens. We thank Tigga Kingston and Joe Chun-Chia Huang for facilitating specimen loans, Beatrix Lanzinger for providing access to literature from the Harrison Institute library and the directors and staff of wildlife sanctuaries and national parks in Thailand for permission and support for the field surveys. We also thank Wilaiwan Chotigeat, Pataraporn Kongmee, Narumon Kunjun, and Thitika Kitpipit for their help in genetic laboratory techniques, and also Singtoe Boonrotpong and Bongkot Wichachucherd for their assistance in genetic analysis. We are indebted to the staff from the Princess Maha Chakri Sirindhorn Natural History Museum, PSU; Zoological Museum at Universiti Malaysia Sarawak, Malaysia (the research was supported by Ministry of Higher Education in Malaysia through Research Acculturation Collaborative Effort grant RACE/G (2)/1107/2013 [15] to FAAK); NSRL at Museum of Texas Tech University; Research Center for Biology, Indonesian Institute of Sciences and the Natural History Museum, London. The research by Vu Dinh Thong is funded by Vietnam National Foundation for Science and Technology Development (NAFOSTED) under grant number 106.11-2012.02. Finally, we are deeply grateful to the Graduate School of PSU, the Center for Biodiversity Conservation, Fauna \& Flora International Cambodia program, and Royal University of Phnom Penh and to the UK Darwin Initiative (Project no's: 18002; EIDPO028), CEPF (Critical Ecosystem Partnership Fund 2009 to 2011), the John D and Catherine D MacArthur Foundation (09-92411-000-GSS), and the Zoological Parks and Gardens Board of Victoria for their steadfast support.

\section{Author details}

'Department of Biology, Faculty of Science, Royal University of Phnom Penh, Confederation of Russia Boulevard, Phnom Penh 12150, Cambodia.

${ }^{2}$ Department of Biology, Faculty of Science, Prince of Songkla University, 15 Karnjanavanich Street, Hat Yai, Songkhla 90110, Thailand. ${ }^{3}$ Centre for Biodiversity Conservation, Faculty of Science, Royal University of Phnom Penh, Room 415, Confederation of Russia Boulevard, Phnom Penh 12150, Cambodia. ${ }^{4}$ Fauna \& Flora International, Cambodia Programme, PO Box 
1380\#19, Street 360, Boeng Keng Kong 1, Chamkarmon, Phnom Penh 12300, Cambodia. ${ }^{5}$ Harrison Institute, Bowerwood House, St. Botolph's Road, Sevenoaks, Kent TN13 3AQ, UK. ${ }^{6}$ Department of Molecular Biotechnology and Bioinformatics, Prince of Songkla University, 15 Karnjanavanich Street, Hat Yai, Songkhla 90110, Thailand. Department of Zoology, Faculty of Resource Science and Technology, Universiti Malaysia Sarawak, Kota Samarahan, Sarawak 94300, Malaysia. ${ }^{8}$ Institute of Ecology and Biological Resources, Vietnam, Academy of Science and Technology, 18 Hoang Quoc Viet Road, Cau Giay District, Hanoi 100000, Vietnam. ${ }^{9}$ Princess Maha Chakri Sirindhorn Natural History Museum, Prince of Songkla University, 15 Karnjanavanich Street, Hat Yai, Songkhla 90110, Thailand.

\section{Received: 28 July 2014 Accepted: 19 January 2015}

\section{Published online: 23 February 2015}

\section{References}

Andersen K (1905) On some bats of genus Rhinolophus, with remarks on their mutual affinities and descriptions of twenty-six new forms. Proc Zool Soc Lond 2:75-145

Baker WJ, Coode MJE, Dransfield J, Dransfield S, Harley MM, Hoffmann P, Johns RJ (1998) Patterns of distribution of Malesian vascular plants. In: Hall R, Holloway JD (eds) Biogeography and geological evolution of Southeast Asia. Backhuys, Leiden

Barclay RMR, Brigham RM (1991) Prey detection, dietary niche breadth, and body size in bats: why are aerial insectivorous bats so small? Am Nat 137(5):693-703

Barclay RMR, Fullard JH, Jacobs DS (1999) Variation in the echolocation calls of the hoary bat (Lasiurus cinereus): influence of body size habitat structure, and geographical location. Can J Zool 77:530-534

Bates JJP, Harrison DL (1997) Bats of Indian subcontinent. Harrison Zoological Museum, Sevenoaks, Kent, England

Bergmans W, Van Bree PJH (1986) On a collection of bats and rats from the Kangean Islands, Indonesia (Mammalia: Chiroptera and Rodentia). Z Saugetierkunde 51:329-344

Chen SF, Rossister SJ, Faulkes CG, Jones G (2006) Population genetic structure and demographic history of the endemic Formosan lesser horshoe bat (Rhinolophus monoceros). Mol Ecol 15:1643-1656, doi:10.1111/j.1365294X.2006.02879.x

Cooper SJB, Reardon TB, Skilins J (1998) Molecular systematics of Australian rhinolophid bats (Chiroptera: Rhinolophidae). Aust J Zool 46:203-220, doi:10.1071/ZO97056

Corbet GB, Hill JE (1992) The mammals of the indomalayan region, the natural history museum publications. Oxford University Press, London

Csorba G, Ujhelyi P, Thomas NM (2003) Horseshoe bats of the world (Chiroptera: Rhinolophidae). Alana Books, Bishops Castle

Darriba D, Taboada GL, Doallo R, Posada D (2012) jModelTest 2: more models, new heuristics and parallel computing. Nat Methods 9(8):772, doi:10.1038/ nmeth.2109

de Bruyn M, Nugroho E, Hossain MM, Wilson JC, Mather PB (2005) Phylogeography evidence for the existence of an ancient biogeographic barrier: the Isthmus of Kra of Kra Seaway. Heredity 94:370-378, doi:10.1038/sj. hdy. 6800613

Francis CM (2008) A field guide to the mammals of Thailand and South-East Asia. Books Co., Ltd, Bangkok

Francis CM, Habersetzer J (1998) Interspecific and intraspecific variation in echolocation call frequency and morphology of horseshoe bats, Rhinolophus and Hipposideros. In: Kunz T, Racey PA (eds) Bat biology and conservation. Smithsonian Institute Press, Washington, DC

Furey NM, Mackie IJ, Racey PA (2009) The role of ultrasonic bat detectors in improving inventory and monitoring surveys in Vietnamese karsts bat assemblages. Curr Zool 55:327-345

Gathorne-Hardy FJ, Syaukani DRG, Eggleton P, Jones DT (2002) Quaternary rainforest refugia in south-east Asia: using termites (Isoptera) as indicators. Biol J Linnean Soc 75:453-466

Good R (ed) (1964) The geographiy of the flowering plants., vol Servies, 3rd edn. London, Longman

Guillén A, Just JB, Ibànez C (2000) Variation in the frequency of the echolocation calls of Hipposideros ruber in the Gulf of Guinea: an exploration of the adaptive meaning of the constant frequency value in rhinolophoid CF bats. J Evol Biol 13:70-80
Hall TA (1999) BIOEDIT: a user-friendly biological sequence alignment editor and analysis program for Windows 95/98/NT. Nucleic Acids Symp Ser 41:95-98

Hall R (2013) The palaeogeography of Sundaland and Wallacea since the Late Jurassic. J Limnol 72(s2):1-17, doi:10.4081/jlimnol.2013.s2.e1

Heaney LR (1991) A synoptic climatic and vegetational change in Southeast Asia. Climatic Change 19:53-61

Heller K-G, Helversen O (1989) Resource partitioning of sonar frequency bands in rhinolophid bats. Oecologia 80:178-186

Hill JE (1959) Bates in limestone of Sarawak. Ann Mag nat Hist 13:85-91

Hill JE, Schlitter DA (1982) A record of Rhinolophus arcuatus (Chiroptera: Rhinolophidae) from New Guinea, with the description of a new subspecies. Ann Carnegie Mus 51:455-464

Huelsenbeck JP, Ronquist F (2001) MRBAYES: Bayesian inference of phylogeny. Bioinformatics 17:754-755

Hughes AC, Satasook C, Bates PJJ, Bumrungsri S, Jones G (2011) Explaining the casuses of the zoogeographic transition around the Isthmus of Kra: using bats as a case study. J Biogeogr 38(12):1-11, doi:10.1111/j.1365-2699.2011.02568.x

Hughes JB, Round PD, Woodruff DS (2003) The Indochinese-Sundaic faunal transition at the Isthmus of Kra: an analysis of resident forest bird species distributions. J Biogeogr 30:569-580

Hutchison CS (1989) Geological evolution of South-east Asia. Clarendon Press, Oxford

Ith S, Soisook P, Bumrumgsri S, Kingston T, Puechmaille SJ, Struebig MJ, Hla Bu SS, Thong VD, Furey MN, Thomas NM, Bates JJP (2011) A taxonomic review of Rhinolophus coelophillus Peters 1867 and R. shameli Tate 1943 (Chiroptera: Rhinolophidea) in continental Southeast Asia. Acta Chiropterologica 13(1):41-59

Ivanova NV, Clare EL, Borisenko AV (2012) DNA barcoding in mammals. In: Kress WJ, Erickson DL (eds) DNA barcodes: methods and protocols. Humana Press, New York, p 485

Jacobs DS, Barclay RMR, Walker MH (2007) The allometry of echolocation call frequencies of insetivorous bats: why do some bats deviate from the pattern? Oecologia 152:583-594, doi:10.1007/s00442-007-0679-1

Jones G, Morton M, Hughes PM, Budden RM (1993) Echolocation, flight morphology and foraging strategies of some West African hipposiderid bats. J Zool London 230:385-400, doi:10.1111/j.1469-7998.1993.tb02691.x

Keng H (1970) Size and affinities of the flora of the Malay Peninsula. J Trop Geogr 31:43-56

Khan FAA, Solari S, Swier VJ, Larsen PA, Abdullah MT, Baker RJ (2010) Systematics of Malaysian woolly bats (Vespertilionidae: Kerivoula) inferred from mitochondrial, nuclear, karyotypic, and morphological data. J Mammal 91 (5):1058-1072, doi:10.1644/09-MAMM-A-361.1

Kingsada P, Douangboubpha B, Ith S, Furey N, Soisook P, Bumrungsri S, Satasook C, Thong VD, Csorba G, Harrison D, Pearch M, Bates P, Thomas N (2011) A checklist of bats from Cambodia, including the first record of the intermediate horseshoe bat Rhinolophus affinis (Chiroptera: Rhinolophidae) with additional information from Thailand and Vietnam. Cambodian J Nat Hist 1:49-59

Kingston T, Lara MC, Jones G, Akbar Z, Kunz TH, Schneider CJ (2001) Acoustic divergence in two cryptic Hopposideros species: a role for social selection? R Soc 268:1381-1386

Kingston T, Rossister SJ (2004) Harmonic hopping in Wallacea's bats. Nature 429:654-657, doi:10.1038/nature02561

Koopman KF (1994) Chiroptera: stystematics. Handbook of zoology, Mammalia, part 60. Walter de Gruyter, Berlin

Lekagul B, McNeely JA (1977) Mammals of Thailand. Assoication for the Conservation of Wildlife. Saha Karn Bhaet Co, Bangkok

Li G, Jones G, Rossister SJ, Chen S-F, Parsons S, Zhang S (2006) Phylogenetics of small horseshoe bats from East Asia based on mitochondrial DNA sequence variation. J Mammal 87(6):1234-1240

Maharadatunkamsi HS, Kitchener DJ, Schmitt LH (2000) Genetic and morphometric diversity in Wallacea: geographical patterning in the horse shoe bat, Rhinolophus affinis. J Biogeogr 27(1):193-201

Mao XG, Zhu GJ, Zhang S, Rossister SJ (2010) Pleistocene climatic cycling drives intra-specific diversification in the intermediate horseshoe bat (Rhinolophus affinis) in Southern China. Mol Ecol 19:2754-2769, doi:10.1111/j.1365294X.2010.04704.X

Morley RJ (2000) Origin and evolution of tropical rain forests. J. Wiley, Chichester

Patrick LE, McCulloch ES, Ruedas LA (2013) Systematics and biogeography of the arcuate horseshoe bat species complex (Chiroptera, Rhinolophidae). Zool Scr 42(6):553-590, doi:10.1111/zsc.12026

Pauwels OSG, David P, Chimsunchart C, Thirakhupt K (2003) Reptiles of Phetchaburi ProvinceWestern Thailand: a list of species, with natural history 
notes, and a discussion on the biogeography at the isthmus of Kra. Nat Hist J Chulalongkorn Univ 3(1):23-25

Pauwels OSG, Laohawat O-A, Naaktae W, Puangit C, Wisutharom T, Chimsunchart C, David P (2002) Reptile and amphibian diversity in Phang-nga province, Southern Thailand. Nat Hist J Chulalongkorn Univ 2(1):25-30

Petit E, Excoffier L, Mayer F (1999) No evidence of bottleneck in the postglacial recolonization of Europe by the noctule bat (Nyctalus noctula). Evolution 53:1247-1258

Rambaut A, Drummond AJ (2007) BEAST: Bayesian evolutionary analysis by sampling trees. BMC Evol Biol 7:214

Rambaut A, Drummond AJ (2009) Tracer, vol Version 1.5., Available from the BEAST site: http://beast.bio.ed.ac.uk/

Richards PW (ed) (1996) The tropical rain forest: an ecological study., vol Servies, 2nd edn. Cambridge, Cambridge University Press

Robinson MF (1996) A relationship between echolocation calls and noseleaf widths in bats of the genera Rhinolophus and Hipposidero. J Zool Lond 239:389-393

Salgueiro P, Coelho MM, Palmeirim JM, Ruedi M (2004) Mitochondrial DNA variation and population structure of the island endemic Azorean bat (Nyctalus azoreum). Mol Ecol 13:3357-3366, doi:10.1111/j.1365294X.2004.02354.X

Shi YF, Cui ZJ, Su Z (2006) The quaternary glaciations and environmental variations in China. Hebei Science and Technology Press, Shijiazhuang

Simmon N (2005) Order Chiroptera. In: Wilson DE, Reeder DM (eds) Mammal species of the world: a taxonomic and geographical reference, 3rd edn. Jhons Hopkin University Press, Baltimore, pp 312-529

Sinha YP (1973) Taxonomic studies on the Indian horseshoe bats of the genus Rhinolophus. Mammalia 37(4):603-630

Soisook P, Burungsri S, Satasook C, Thong VD, Hla Bu SS, Harrison DL, Bates PJJ (2008) A taxonomic review of Rhinolophus stheno and R. malayanus (Chiroptera: Rhinolophidae) from continental Southeast Asia: an evaluation of echolocation call frequency in descrimating between cryptic species. Acta Chiropt 10(2):221-242, doi:10.3161/150811008X414818

Stanley HF, Casey S, Carnahan JM, Goodman S, Harwood J (1996) Worldwide patterns of mitochondrial DNA differentiatoin in the harbor seal (Phoca vitulina). Mol Biol Evol 13:368-382

Tamura K, Peterson D, Peterson N, Stecher G, Nei M, Kumar S (2011) MEGA5: molecular evolutionary genetics analysis using maximum likelihood, evolutionary distance, and maximum parsimony methods. Mol Biol Evol 28:2731-2739, doi:10.1093/molbev/msr121

Thabah A, Rossister SJ, Kingston T, Zhang S, Parsons S, Mya KM, Zubaid A, Jones G (2006) Genetic divergene and echolocation call frequency in cryptic species of Hipposideros larvatus s. I. (Chiroptera: Hipposideridae) from the Indo-Malayan region. Biol J Linnean Soc 88:119-130

Thomas NM (1997). A systematic review of selected Afro-Asiatic Rhinolophidae (Mammalia: Chiroptera): an evaluation of taxonomic methodology. PhD Thesis, University of Aberdeen

Thompson JD, Gibson TJ, Plewniak F, Jeanmougin F, Higgins DG (1997) The CLUSTAL_X Windows interface: flexible strategies for multiple sequence alignment aided by quality analysis tools. Nucleic Acids Res 25:4876-4882, doi:10.1093/nar/25.24.4876

Thong VD (2011) Systematics and echolocation of rhinolophoid bats (Mammalia: Chiroptera) in Vietnam. University of Tubingen, Tubingen, Germany

Tougard C (2001) Biogeography and migration routes of large mammal faunas in South-East Asia during the late middle Pleistocene: focus on the fossil and extant faunas from Thailand. Palaeogeogr Palaeoclimatol Palaeoecol 168:337-358

van Steenis CGGJ (1950) The delimitation of Malesia and its main plant geographical divisions. Flora Malesiana 1(1):Ixx-Ixxv

Voris HK (2000) Map of Pleistocene sea levels in Southeast Asia: shorelines, river systems and time durations. J Biogeogr 27:1153-1167

Whitmore TC (ed) (1984) Tropical rainforests of the Far East., vol Servies, 2nd edn. Oxford University Press, Oxford

Wikranmanayake E, Dinerstein E, Loucks C, Olson D, Morrison J, Lamoreux J, McKnight M, Hedao P (2002) Terrestrial ecoregions of the Indo-Pacific: a conservation assessment. Island Press, Washington DC

Wilkison GS, Chapman AM (1991) Length and sequence variation in evening bat D-loop mtDNA. Genetics 128:607-617

Woodruff DS (2003) Neogene marine transgressions, palaeogeography and biogeographic trasitions on the Thai-Malay Peninsula. J Biogeogr 30:551-567
Woodruff DS, Turner LM (2009) The Indochinesd-Sundaic zoogeographic transition: a description and analysis of terrestrial mammals species distributions. J Biogeogr 30:1-19, doi:10.1111/j.1365-2699.2008.02071.x

Woodruff DS (2010) Biogeography and conservation in Southeast Asia: how 2.7 million years of repeated environmental fluctuations affect today's patterns and the future of the remaining refugial-phase biodiversity. Biodivers Conserv 19:919-941

\section{Submit your manuscript to a SpringerOpen ${ }^{\odot}$ journal and benefit from:}

- Convenient online submission

- Rigorous peer review

- Immediate publication on acceptance

- Open access: articles freely available online

- High visibility within the field

- Retaining the copyright to your article

Submit your next manuscript at $\gg$ springeropen.com 